\title{
Behavioural studies on eriophyoid mites: an overview
}

\author{
Katarzyna Michalska $\cdot$ Anna Skoracka $\cdot$ Denise Navia $\cdot$ \\ James W. Amrine
}

Received: 29 March 2009/Accepted: 11 September 2009/Published online: 25 September 2009

(C) Springer Science+Business Media B.V. 2009

\begin{abstract}
Eriophyoid mites are excellent candidates for ethological research using the approaches of behavioural ecology and sociobiology. These tiny haplodiploid mites are highly specialized plant parasites, producing galls, forming nests, inhabiting refuges or living freely on plants. They reproduce via spermatophores deposited on a substrate and without pairing, which is a fascinating, though still poorly understood, mode of reproduction widespread in some groups of arthropods. Eriophyoid males can be involved in external sperm competition. In some species they also guard pre-emergent females and deposit spermatophores beside them. Although slow-walking, the minute eriophyoid mites can disperse for long distances on air currents or specific animal carriers. After landing on a plant they can distinguish between suitable and unsuitable hosts. Biological observations on a deuterogynous species indicate that parasociality could occur among eriophyoid mites. Many eriophyoids are of economic importance. Knowledge of their behaviour may promote understanding their ecology, may resolve problems in their phylogeny and may help developing methods for their control. In this paper, attention is directed to dispersal modes of eriophyoid mites, their feeding and host acceptance, spermatophore deposition and mating, defence against predators, and social behaviour.
\end{abstract}

\footnotetext{
K. Michalska $(\bowtie)$

Department of Applied Entomology, Warsaw University of Life Sciences, Nowoursynowska 159, 02-776 Warsaw, Poland

e-mail: katarzyna_michalska@sggw.pl
}

\author{
A. Skoracka \\ Department of Animal Taxonomy and Ecology, Institute of Environmental Biology, \\ Faculty of Biology, Adam Mickiewicz University, Umultowska 89, 61-614 Poznań, Poland \\ D. Navia \\ Laboratory of Plant Quarantine, Embrapa Genetic Resources and Biotechnology, \\ CP 02372, Brasília, DF 70.770-900, Brazil
}

J. W. Amrine

West Virginia University, Morgantown, WV, USA 
Keywords Eriophyoidea - Aerial dispersal - Antipredator behaviour .

Host-acceptance behaviour $\cdot$ Reproductive behaviour $\cdot$ Social behaviour

\section{Introduction}

Although eriophyoid mites were first noted in the literature about 270 years ago and have been thoroughly investigated since the mid-19th century, aspects of their behaviour have only been studied for a few decades, and rather sparsely. Microscopic size of eriophyoids and their tendency to hide within plant structures (Lindquist 1996) make direct observations of these mites difficult. These factors, together with difficulties in handling and rearing them (e.g. within galls) probably was the reason preventing significant research in behavioural investigations.

In the past century only a few topics on eriophyoid behaviour have been examined. Several fundamental publications describing their ability to discriminate between different host plants, describing feeding mechanisms, spermatophore deposition and picking up sperm by females, and the possibility of the existence of different dispersal strategies have emerged. All have been reviewed by Oldfield and Michalska (1996), Sabelis and Bruin (1996), and Westphal and Manson (1996). Additionally, the effect of temperature and photoperiod, and different wavelengths of light on the behaviour of eriophyoid mites have been studied (Smith 1959; Sternlicht 1969).

Eriophyoidea are an economically important group due to the direct damage they can cause to their hosts, their ability to transmit serious plant diseases, and also due to the possibility of using them as biological agents for weed control (Lindquist et al. 1996). Information on the behaviour of these tiny plant parasites could be of great practical importance, e.g. to monitor pest populations or to develop better control methods. In addition, such features like high host specialization, sex dissociation and social behaviors (Oldfield 1996; Oldfield and Michalska 1996; Britto et al. 2008) make eriophyoid mites suitable candidates for both ethological research as well as investigations using the approach of behavioural ecology. By dint of technological advances in microscopy and photography and in rearing methods, behavioural observations of these minute mites have become more routine in recent years.

The aim of this paper is to review and update the information on the behaviour of eriophyoid mites, indicating some so far unexplored avenues of their behaviour and evolution.

\section{Foraging behaviour}

The evolutionary success of eriophyoid mites, as for any animal, depends on reproductive success which in turn depends on effective foraging behaviour. Animals behave in such a way as to find, capture and consume food containing adequate nutrition while spending the least amount of time and energy possible in doing so (MacArthur and Pianka 1966). The overall survival of phytophagous arthropods depends on dispersal to suitable host plants, whether close by or far away. For eriophyoid mites, which are not adapted for active dispersal between plants, both abandoning a plant and finding a new one is especially difficult and risky. Thus, the mode of dispersal is a key component of the foraging strategy for these mites, and influences their subsequent host acceptance and feeding behaviour. 
Dispersal modes

For eriophyoid mites the proper host plant is a crucial factor for survival and reproduction. However, a portion of the mites actively disperse when conditions are suitable- high temperatures and humidity, approaching low pressure area, significant wind, etc.-independent of the condition of the host. Thus, in fact, eriophyoid mites can choose one of two things: stay on the plant and continue to increase the size of population, or disperse and take a chance on finding and colonizing a new habitat. But the problem is that tiny eriophyoid mites cannot actively seek new hosts. The only active mode of eriophyoid dispersal is by walking within one plant or from one plant to another if they touch one another. Except for this, only passive methods of dispersal have been observed for eriophyoid mites, i.e. (1) transferrance by air currents, (2) phoresy on animal carriers, or (3) dispersal by rain (Jeppson et al. 1975; Schliesske 1990).

Examples of all four modes can be found in the literature. However, among them aerial dispersal was considered the most important (Lindquist and Oldfield 1996; Zhao and Amrine 1997a, b). Many authors reported eriophyoids in the air on evidence from catches on sticky traps or on plates (e.g. Nault and Styer 1969; Lindquist and Oldfield 1996 and references therein, see also Table 1). Moreover, authors have observed different behavioural adaptations which were interpreted as facilitating aerial dispersal: initiating the takeoff for dispersal by moving to the plant tips and standing up on their anal lobes (Fig. 1), moving the legs rapidly, arching bodies and leaping into the air, raising the hind part of the body while standing on their forelegs, forming swarms of thousands of individuals at leaf tips (Sabelis and Bruin 1996), and jumping so as to allow the mite to become airborne (Ozman and Golsby 2005). Although considered the most important, aerial dispersal has been regarded as the most risky mode of dispersal (Sabelis and Bruin 1996). When highly specialized animals move by wind, the probability of landing on a suitable host is very low. That is why Sabelis and Bruin (1996) proposed that aerial dispersal is advantageous for species with wide host ranges, giving Abacarus hystrix (Nalepa) as an example. However, recent studies have shown that this aerially dispersed grass-inhabiting ostensible generalist is in fact a complex of highly specialized species (Skoracka and Kuczyński 2006; Skoracka 2008). Furthermore, special behaviours interpreted as adaptations for aerial dispersal can be regarded not only as behaviours increasing the probability of launching into the atmosphere but also as increasing the probability of attaching to a passing object, such as an insect, a larger mite, or even a human (e.g. Gibson and Painter 1957; Duffner et al. 2001).

Eriophyoid mites attaching to other animals have been reported by several authors and this phenomenon was often interpreted as phoresy (e.g. Massee 1928; Gibson and Painter 1957; Shvanderov 1975; Waite and McAlpine 1992; see also Table 1). According to Lindquist and Oldfield (1996) eriophyoid mites do not show clear phoretic morphological adaptations, such as the pedicels or claws which can be found in other phoretic mites. Also, no specific adaptations for selectivity toward a more favourable carrier have been observed for eriophyoid mites. Thus, Lindquist and Oldfield (1996) concluded that the use of carriers by eriophyoid mites is an accidental behaviour. Even if accidental, transport by hostspecific carriers would seem to be more efficient than aerial dispersal, and it would guarantee a greater possibility of finding a specific host (Sabelis and Bruin 1996), provided that eriophyoids can distinguish host-specific carriers from non-host-specific carriers that could take them even further away from a host-plant than the wind.

Wind and carriers have been the dispersal modes most often discussed in the literature for eriophyoids (Lindquist and Oldfield 1996, Sabelis and Bruin 1996, Lindquist 1998). 
Table 1 Studies on eriophyoid mites dispersal

\begin{tabular}{|c|c|c|c|c|c|}
\hline \multirow[t]{2}{*}{ Species } & \multicolumn{4}{|c|}{ Mode of dispersal } & \multirow[t]{2}{*}{ References } \\
\hline & Ambulatory & Wind & Rain & Carriers & \\
\hline Abacarus hystrix (Nalepa) & & $\mathrm{X}$ & & & $\begin{array}{l}\text { Nault and Styer (1969); } \\
\text { Frost (1997) }\end{array}$ \\
\hline Acalitus essigi (Hassan) & $X$ & $\mathrm{X}$ & & & $\begin{array}{l}\text { Hanson (1933); Davies } \\
\text { et al. (2001) }\end{array}$ \\
\hline $\begin{array}{l}\text { Acalitus hibisci Mondal et } \\
\text { Chakrabarti }\end{array}$ & $X$ & & & & $\begin{array}{l}\text { Chakrabarti and } \\
\text { Chakrabarti (2005) }\end{array}$ \\
\hline $\begin{array}{l}\text { Acalitus phloeocoptes } \\
\text { (Nalepa) }\end{array}$ & & $\mathrm{X}$ & & & Sternlicht et al. (1973) \\
\hline Aceria chibaensis (Kadono) & & $X$ & & & Kadono et al. (1982) \\
\hline Aceria spp. & & & & Leafhoppers & $\begin{array}{l}\text { Painter and Schesser } \\
\text { (1954) }\end{array}$ \\
\hline Aceria cynodoniensis Sayed & & & & Mole crickets & Cromroy (1983) \\
\hline Aceria guerreronis Keifer & $X$ & $\mathrm{X}$ & & $\begin{array}{l}\text { Bees, ants, and } \\
\text { other } \\
\text { insects, bats }\end{array}$ & $\begin{array}{l}\text { Julia and Mariau } \\
\text { (1979), Griffith } \\
\text { (1984), Moore and } \\
\text { Alexander (1987), } \\
\text { Schliesske (1990), } \\
\text { Sumangala and Haq } \\
\text { (2005) }\end{array}$ \\
\hline Aceria litchii (Keifer) & $X$ & $\mathrm{X}$ & & $\begin{array}{l}\text { Honey bees, } \\
\text { Phytoseiids }\end{array}$ & $\begin{array}{l}\text { Mishra (1912), Lall and } \\
\text { Rahman (1975), } \\
\text { Waite and McAlpine } \\
\text { (1992), Waite (1999), } \\
\text { G.K. Waite unpubl. }\end{array}$ \\
\hline Aceria loewi (Nalepa) & & & & $\begin{array}{l}\text { Spiders, } \\
\text { dipterans, } \\
\text { aphids, } \\
\text { coleopterans }\end{array}$ & Shvanderov (1975) \\
\hline Aceria tosichella Keifer & & $\mathrm{X}$ & & $\begin{array}{l}\text { Aphis, trips, } \\
\text { greenbugs }\end{array}$ & $\begin{array}{l}\text { Slykhuis and Andrews } \\
\text { (1953), Pady (1955), } \\
\text { Slykhuis (1955), } \\
\text { Staples and Allington } \\
\text { (1956, 1959), Gibson } \\
\text { and Painter (1957), } \\
\text { Nault and Styer } \\
\text { (1969), Harvey and } \\
\text { Martin (1980, 1988), } \\
\text { Harvey et al. (1990), } \\
\text { Brey (1998), Thomas } \\
\text { and Hein (2003), Liu } \\
\text { et al. (2005) }\end{array}$ \\
\hline Aculodes mckenziei (Keifer) & & $\mathrm{X}$ & & & Nault and Styer (1969) \\
\hline Aculodes dubius (Nalepa) & & $\mathrm{X}$ & & & Nault and Styer (1969) \\
\hline Aculops lycopersici (Tryon) & & & & $\begin{array}{l}\text { Aphids, } \\
\text { human }\end{array}$ & $\begin{array}{l}\text { Grahl and Leuprecht } \\
\text { (1998), Tanaka and } \\
\text { Shibao (2003) }\end{array}$ \\
\hline Aculus comatus (Nalepa) & & $\mathrm{X}$ & & & $\begin{array}{l}\text { Krantz (1973), Duffner } \\
\text { et al. (2001) }\end{array}$ \\
\hline
\end{tabular}


Table 1 continued

\begin{tabular}{|c|c|c|c|c|c|}
\hline \multirow[t]{2}{*}{ Species } & \multicolumn{4}{|c|}{ Mode of dispersal } & \multirow[t]{2}{*}{ References } \\
\hline & Ambulatory & Wind & Rain & Carriers & \\
\hline $\begin{array}{l}\text { Aculus fockeui (Nalepa et } \\
\text { Trouessart) }\end{array}$ & & $X$ & $X$ & Human & $\begin{array}{r}\text { Barke et al. (1972), } \\
\text { Schliesske (1977) }\end{array}$ \\
\hline $\begin{array}{l}\text { Aculus schlechtendali } \\
\text { (Nalepa) }\end{array}$ & & $\mathrm{X}$ & & & Duffner et al. (2001) \\
\hline Calepitrimerus vitis (Nalepa) & $\mathrm{X}$ & $\mathrm{X}$ & & Human & $\begin{array}{l}\text { Duffner et al. (2001), } \\
\text { Gabi and Mészáros } \\
\text { (2003) }\end{array}$ \\
\hline $\begin{array}{l}\text { Cecidophyopsis ribis } \\
\text { (Westwood) }\end{array}$ & & $\mathrm{X}$ & $\mathrm{X}$ & $\begin{array}{l}\text { Aphids, } \\
\text { ladybeetles, } \\
\text { honey bees, } \\
\text { spiders, } \\
\text { dipterans, } \\
\text { aphids, } \\
\text { coleopterans }\end{array}$ & $\begin{array}{l}\text { Massee (1928), Smith } \\
\text { (1960), Behrens } \\
\text { (1964), van de Vrie } \\
\text { (1967), Shvanderov } \\
\text { (1975), Duffner et al. } \\
\text { (2001) }\end{array}$ \\
\hline $\begin{array}{l}\text { Cecidophyopsis vermiformis } \\
\text { (Nalepa) }\end{array}$ & $X$ & & & & $\begin{array}{l}\text { Burgess and Thompson } \\
\text { (1985) }\end{array}$ \\
\hline Davisella breitlowi (Davis) & & $X$ & & & Davis (1964) \\
\hline $\begin{array}{l}\text { Diptacus gigantorhynchus } \\
\text { (Nalepa) }\end{array}$ & & $\mathrm{X}$ & $X$ & Human & Schliesske (1977) \\
\hline Epitrimerus pyri (Nalepa) & $X$ & $X$ & & & $\begin{array}{l}\text { Easterbrook (1978, } \\
\text { 1979), Herbert } \\
\text { (1979), Bergh (1992), } \\
\text { Bergh and Judd } \\
\text { (1993), Duffner et al. } \\
\text { (2001) }\end{array}$ \\
\hline $\begin{array}{l}\text { Eriophyes armeniacus } \\
\text { Bagdasarian }\end{array}$ & $\mathrm{X}$ & & & & $\begin{array}{l}\text { Oganezova and } \\
\text { Pogosova (1994) }\end{array}$ \\
\hline $\begin{array}{l}\text { Eriophyes emarginatae } \\
\text { Keifer }\end{array}$ & $\mathrm{X}$ & & & & Oldfield (1969) \\
\hline Eriophyes laevis (Nalepa) & $X$ & & & & Vuorisalo et al. (1989) \\
\hline $\begin{array}{l}\text { Eriophyes pyri } \\
\quad \text { (Pagenstecher) }\end{array}$ & & $X$ & & & Duffner et al. (2001) \\
\hline Notostrix jamaicae Keifer & & $X$ & $X$ & $\mathrm{X}$ & Schliesske (1990) \\
\hline Phyllocoptes abaenus Keifer & & $\mathrm{X}$ & $\mathrm{X}$ & Human & Schliesske (1977) \\
\hline $\begin{array}{l}\text { Phyllocoptes gracilis } \\
\text { (Nalepa) }\end{array}$ & $\mathrm{X}$ & & & & van Dinther (1951) \\
\hline $\begin{array}{l}\text { Phyllocoptruta oleivora } \\
\text { (Ashmead) }\end{array}$ & $X$ & $X$ & & & $\begin{array}{l}\text { McCoy (1979), Bergh } \\
\text { and McCoy (1997), } \\
\text { Bergh (2001), Bergh } \\
\text { and Smith (2001) }\end{array}$ \\
\hline Phytoptus avellanae Nalepa & $\mathrm{X}$ & & & & $\begin{array}{l}\text { Burgess and Thompson } \\
\text { (1985) }\end{array}$ \\
\hline Retracrus elaeis Keifer & & $X$ & $X$ & $\mathrm{X}$ & Schliesske (1990) \\
\hline $\begin{array}{l}\text { Tegonotus acutilobus } \\
\text { (Nalepa) }\end{array}$ & & $\mathrm{X}$ & & & Duffner et al. (2001) \\
\hline $\begin{array}{r}\text { Floracarus perreperae } \\
\text { Knihinicki et Boczek }\end{array}$ & & $X$ & & & $\begin{array}{l}\text { Ozman and Goolsby } \\
\text { (2005) }\end{array}$ \\
\hline
\end{tabular}


Table 1 continued

\begin{tabular}{|c|c|c|c|c|c|}
\hline \multirow[t]{2}{*}{ Species } & \multicolumn{4}{|c|}{ Mode of dispersal } & \multirow[t]{2}{*}{ References } \\
\hline & Ambulatory & Wind & Rain & Carriers & \\
\hline Different species & & $\mathrm{X}$ & & & $\begin{array}{l}\text { Mumcuoglu and Six } \\
\text { (1974), Schliesske } \\
\text { (1979), } \\
\text { Somchoudhury et al. } \\
\text { (1985), Zhao and } \\
\text { Amrine }(1997 \mathrm{a}, \mathrm{b})\end{array}$ \\
\hline Different species & & & & Aphids & Batchelor (1952) \\
\hline
\end{tabular}

Fig. 1 Aceria tulipae (Keifer) standing erect on the caudal sucker

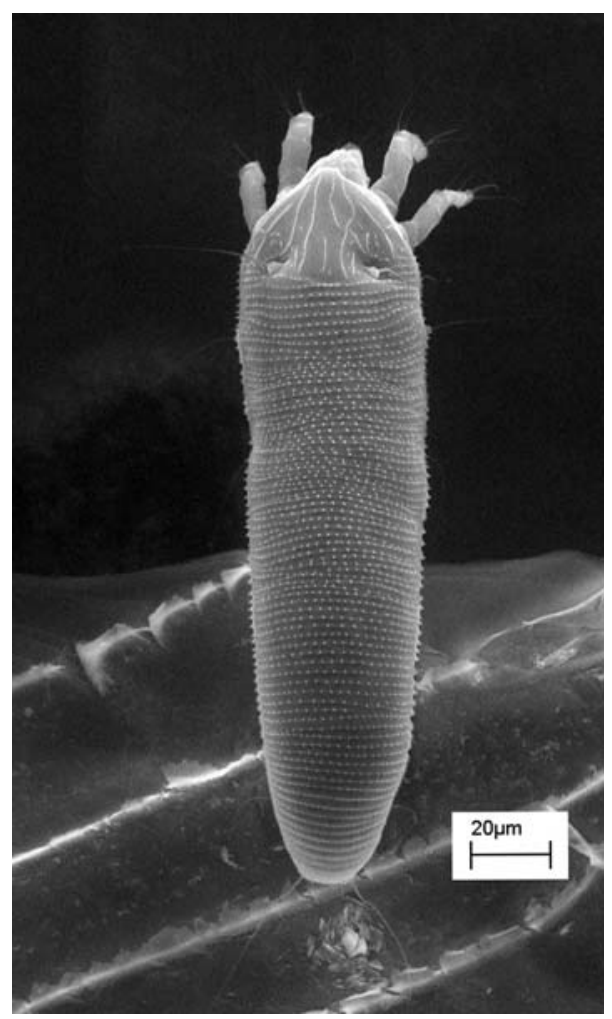

Authors have debated which mode is most often used and the most beneficial for eriophyoid mites. They have analyzed different factors (e.g. host availability, degree of mitehost specificity, mite adaptations) and tried to detect patterns in eriophyoid dispersal. Sabelis and Bruin (1996), however, have cautioned against such interpretations due to the lack of support by empirical data. Thus, the difficulty with finding clear answers results from the scarcity of studies regarding this topic.

Since these last significant reviews regarding eriophyoid dispersal, not much new information has been provided (see Table 1). In spite of the fact that dispersal is the key trait of eriophyoid foraging success, the mode of dispersal has been observed or recorded for only about $2.5 \%$ of approximately 4,000 described species. Considering the scarcity of 
Fig. 2 The number of species versus mode of dispersal derived from search of the literature, from 1912 to 2008. Please note that several authors indicated two or more dispersal modes for the same species, sometimes in the same study

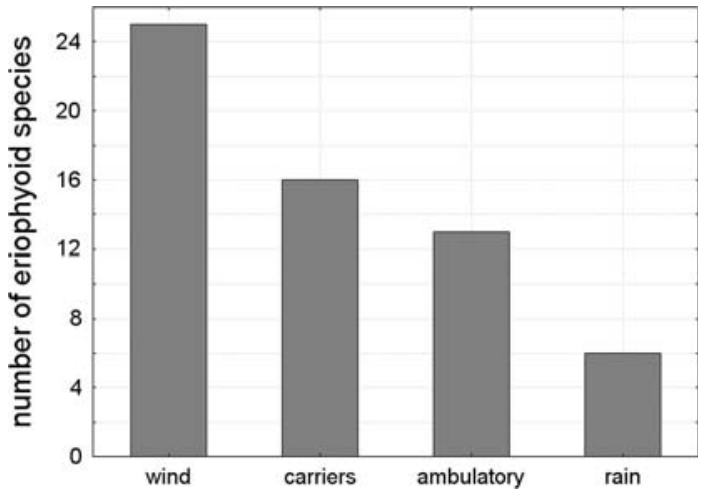

experimental data, it is difficult to draw general conclusions and definitely answer the question of which form of dispersal mode plays the more significant role in eriophyoid mites, if any. Table 1 provides a summary of present knowledge of cases of eriophyoid dispersal. These data have shown that dispersal by wind was reported the most frequently (Fig. 2). Also, Zhao and Amrine (1997a), who collected 10,000 mites in one small container of water in daily collections over just one year and captured more mites on windy days compared to calm ones, have proved that this way was clearly dominant over any other mode of dispersal. Two other modes, i.e. by carriers and ambulatory, occurred rarely when compared to wind, and dispersal by rain had the lowest frequency. Ambulatory movement is, however, very important within a plant or a tree, or in hedges, pastures, forests or other habitats, where branches or leaves of suitable plants contact one another or are close together.

Host acceptance and feeding

Host acceptance is thought to reflect the suitability of hosts for herbivore survival (Courtney et al. 1989; Singer et al. 1989). Irrespective of the method of transport (wind or carrier) when the eriophyoid mite ends up on a non-host, it losses time finding a new suitable host. Thus, an ability to quickly discriminate between host and non-host may well confer selective advantage.

It has been shown that few eriophyoid species can apparently distinguish between acceptable and unacceptable hosts. Differences in host acceptance can be measured as differences in reproduction and development on various hosts (Bergh and Weiss 1993; Chen et al. 2000; Skoracka and Kuczyński 2006) or directly by behavioural observations. For example, Aceria tosichella Keifer behaved differently according to the quality of their grass host plant, i.e., it stayed on hosts during periods of active plant growth and dispersed when host plant quality was deteriorating because of heavy feeding damage (Nault and Styer 1969). Thus, non-preference of the host can be exhibited by initiating new dispersal behaviour.

Kozłowski and Boczek (1987) and Kozłowski (1995) showed that feeding behaviour (i.e. time of probing and feeding) of Aculus schlechtendali (Nalepa) was different on various apple varieties. According to Gibson (1974), A. hystrix fed only on three among 11 grass species tested. Other studies have demonstrated that overall activity and the part of the plant occupied by A. hystrix differed among selected grass species (Skoracka et al. 2007). On familiar hosts, females of A. hystrix were not very active and showed little tendency to move. They spent most of their time resting in furrows on the upper leaf 
surface. In contrast, females on non-hosts were generally more active and mobile, spending more time walking, running, and climbing over the whole plant surface including sites that are not typical for them, such as leaf margins, ligules, bases, and stems. In addition, they showed a high tendency toward dispersal. The behavioural reaction to non-hosts by A. hystrix was consistent with reduced individual fitness observed previously for the same populations on the same novel hosts, whereas behaviourally accepted hosts were the same ones on which these populations survived better and had higher fecundity (Skoracka and Kuczyński 2006). Thus, because the mites gain in fitness by discriminating between hosts, their behaviour was interpreted as adaptive discrimination.

Finally, after landing on the host and discriminating whether it is a proper one, the eriophyoid mite can start to feed. After probing, which takes several seconds, the mite takes a typical feeding stance, i.e. it slightly bends its body and anchors the rostrum to the host surface and contracts the telescopic palpal segments, which allows protrusion of the cheliceral stylets for a short distance into the plant tissues (Krantz 1973; Gibson 1974; McCoy and Albrigo 1975; Nuzzaci 1976). Information concerning the feeding behaviour of eriophyoid mites was summarized by Westphal and Manson (1996) and no new detailed data have been provided since.

Future directions

As indicated above, data regarding the foraging of eriophyoid mites are available only for a small number of species. It is obvious that knowledge of the mechanisms and factors influencing dispersal, host acceptance and feeding behaviour may help in defining strategies on management and estimating the risk posed by pest species to new areas. This topic requires more research. Some suggestions are given below.

\section{Dispersal}

Investigations into longevity of dispersing mites, tolerance of extreme conditions (low temperatures and pressures at high altitudes) and the potential for multiple launches from undesirable host plants should be made as these characteristics may help to ensure successful aerial dispersal.

Females are regarded as the dispersing stage in eriophyoid mites (Lindquist and Oldfield 1996). However, males and nymphs are found dispersing as well. Theoretically, a single eriophyoid female may be able to give rise to an entire population. Thus, a newly founded population may be genetically distinct from the source population. How often the founder effect occurs in nature and whether it influences the genetic differentiation among eriophyoid mite species should be studied.

To be successful in finding a proper host, eriophyoid mites may attach to specific carriers for dispersal. Research should try to determine which potential carriers can serve as specific vectors and guarantee eriophyoid success, and which are accidental and attachment to them may have no more success than aerial dispersal. Also, survival ability of eriophyoid mites on carriers, and the carriers' reactions to the presence of eriophyoid mites should be studied.

Generally, eriophyoid mites may use different means of dispersal. There is a question about the factors influencing each of these modes; or perhaps choosing a mode of dispersal 
is accidental? It should also be determined whether particular species may use a combination of different dispersal techniques.

\section{Host acceptance and feeding}

It is important to recognize the decision process that leads mites to either accept or reject a given host. Suitability of the host plant can depend upon a number of factors such as a plant's chemical composition, nutritional quality and toxicity, the plant's physical characteristics, stage of growth, structure, prevalence of natural enemies or microenvironment (Thompson and Pellmyr 1991; Bernays and Chapman 1994). Which of them play a role in host plant discrimination in specific eriophyoid mites should be tested. Great attention should be paid to the mite solenidion, which is the sensory organ informing the mite about the chemical composition of the substrate. The host plant's chemical interaction with the solenidion, especially the ability of eriophyoid mites to discriminate among thousands of volatile compounds on plant surfaces and being attracted to only a very few of them, would be a very interesting area of study.

For phytophagous arthropods, host acceptance behaviour is a key character responsible for host plant specialization (Jaenike 1990). Thus, using behavioural data, host specificity of eriophyoids can be tested. Testing host acceptance is especially important with respect to invasive species which may be able to extend their host range and become a problem in ecosystems. An example of such an invasive species is Aceria guerreronis Keifer which has recently spread to most coconut production areas worldwide. Moore and Howard (1996) hypothesised that the original host of this mite is a non-coconut palm from which the mite switched to coconut palm when it became more extensive in the Americas or Africa. This hypothesis was supported by Navia et al. (2005) on the basis of molecular studies of American, African and Asian populations. However, recent information on the occurrence of A. guerreronis from coconut unproductive hybrids, possibly ancestral stock in Queensland, Australia (Ochoa personal comm. 2008) may lead to a change in this scenario. It may be possible that the mite originated from the coconut native region, the Indo-Pacific, and from there dispersed to the Americas and Africa. Both hypotheses indicate that the mite has extended its host range along its invasion routes. In addition to coconut, A. guerreronis has also been found infesting Borassus flabellifer L. in Asia (India and Sri Lanka), and Syagrus romanzoffiana (Cham.) Glassman in North America (California, USA).

Another example of expansion of host range seems to be Aculops lycopersici (Tryon). It has been suggested that the original host plant of this mite was a wild solanaceous plant somewhere in the Americas, and its association with tomato is recent (Oldfield 1996). Possibly, the original small and unproductive plant may have been resistant to A. lycopersici. Breeding productive tomatoes probably resulted in loss of resistance to the mite (a similar situation may have happened with the coconut palm tree). Host acceptance tests could help to verify this hypothesis.

It would be very important to investigate genetic and environmental causes influencing host acceptance behaviour in eriophyoid mites and to detect factors affecting mite transfer to new hosts. Also, finding genes responsible for resistance in original hosts to eriophyoid mites could be helpful in developing future mite control on cultivated plants.

Many other issues, e.g. responses and sequences associated with feeding, rhythmic patterns of feeding, and time intervals of probing and cell penetration should be tested among other eriophyoid species, especially species able to transmit plant viruses. 


\section{Sexual behaviour}

Mating of eriophyoids was a puzzle until the publication by Oldfield et al. (1970) reporting that sperm transfer by these mites is indirect and takes place via minute, stalked spermatophores (8-25 $\mu \mathrm{m}$ long; head diameter 9-19 $\mu \mathrm{m})$ deposited on the plant surface. The authors described the spermatophores of several species representing all three families of the superfamily Eriophyoidea. Behavioural observations on Aculus fockeui (Nalepa and Trouessart) [syn. Aculus cornutus (Banks)] and Phyllocoptruta oleivora (Ashmead) have revealed that eriophyoid males can deposit spermatophores in the absence of females. Also, females of $A$. fockeui did not require any assistance from males in picking up sperm from a spermatophore. Sexual 'independence' of males and females has been confirmed in the following eriophyoid species: Aceria sheldoni (Ewing) (Sternlicht and Goldenberg 1971; Sternlicht and Griffiths 1974), Epitrimerus pyri (Nalepa), A. schlechtendali (Oldfield 1988), Acalitus essigi (Hassan), Aculops allotrichus (Nalepa) (syn. Vasates robiniae Nalepa) (Michalska and Boczek 1991; Michalska 1999), Cecidophyopsis hendersoni (Keifer) (Michalska and Shi 2004), and Abacarus hystrix (Skoracka, unpubl.). This so called 'sex dissociation' (syn. mate dissociation or non-pairing) is widespread in several groups of arthropods including Arachnida (mites and pseudoscorpions), Hexapoda (collembolans and diplurans), Pauropoda, Symphyla and Diplopoda (polyxenids) (for review see Alexander 1964; Schaller 1971; Thomas and Zeh 1984; Proctor 1998). In mites, apart from eriophyoids, many other prostigmatic mites (rev. Thomas and Zeh 1984; 1984; Witte 1991; Proctor 1992, 1998; Witte and Döring 1999) and most oribatids (rev. Schaller 1971) are also dissociated. Most non-pairing organisms are aquatic or terrestrial often inhabiting soil or leaf-litter. The eriophyoids are the only known group of obligatory herbivores exhibiting this mode of reproduction.

Sex dissociation can be complete or incomplete. If it is incomplete, as in some water mites, spermatophore deposition is triggered only by previous contact with females or their odours (Proctor 1992). In eriophyoid mites, however, as can be inferred from the observations on A. fockeui, A. allotrichus and C. hendersoni, males can deposit spermatophores in total isolation from both conspecifics and their odours (Oldfield et al. 1970; Michalska and Boczek 1991; Michalska and Shi 2004; Michalska unpubl.).

It is commonly acknowledged that the high density of a population may favour sex dissociation, as it also increases the availability of receptive females and thereby the probability that spermatophores will be visited by females (Alexander 1964; Schaller 1971; Thomas and Zeh 1984; Proctor 1998). It also appears to be true for eriophyoid mites, as they live gregariously on plants and often develop in high population densities (Sabelis and Bruin 1996). By contrast, in sparse populations, males should produce numerous spermatophores in order to increase female-spermatophore encounter rate, which seems to be effective only in extremely mesic habitats with long-lasting viability of spermatophores (Thomas and Zeh 1984; Proctor 1998). As shown by the tests with A. fockeui, eriophyoid spermatophores can be viable for a relatively long time, up to 3 days after deposition on a leaf (Oldfield et al. 1970; Oldfield and Newell 1973), what could additionally favour sexual 'independence' of eriophyoid males.

Spermatophores of sex dissociated arthropods are small structures often difficult to be found by females in the vast volume of water or spatially intricate soil, litter and vegetation (Witte 1991; Proctor 1992, 1998). Furthermore, they are exposed to external sperm competition which may additionally diminish the chances that a female picks up a spermatophore of a particular male (Proctor 1992, 1998). Thus, non-pairing males are known to use the whole range of signaling devices (pheromone plume, signaling threads, zigzag 
secretions) and behavioural tactics aimed at increasing the probability of visiting their spermatophores by females (Witte 1991; Proctor 1992; Proctor 1998). In this paper we focus on these issues putting stress on factors influencing spermatophore deposition by males, picking up sperm from spermatophores by females, contacts between sexes and avoidance of external sperm competition.

\section{Attraction to spermatophores}

Although some females of $A$. fockeui must have bumped into spermatophores to pick up sperm, others clearly changed their behaviour (they walked slower, on stiffened legs) when approaching a spermatophore, which may indicate its recognition via an emitted attractant (Oldfield et al. 1972). Also, as in other non-pairing arthropods, there is a gradual loss of the attractiveness of aging spermatophores to the females (Oldfield et al. 1970; Oldfield and Newell 1973; see also Proctor 1998) implying probably the simultaneous decrease of pheromone concentration in eriophyoid spermatophores.

It is a common view that the placement of spermatophores into groups by indirect sperm transferring arthropods helps to increase the pheromone-mediated attraction to sperm (Proctor 1998; Witte and Döring 1999). Males form rows or fields of their own spermatophores or, 'stealing' the pheromonal plume, they add spermatophores to those previously deposited by other males. Also, in eriophyoid mites, both free-living A. hystrix (Skoracka unpubl.), Anthocoptes ribis Massee, A. shlechtendali, A. allotrichus, A. fockeui, Rhyncaphytoptus ulmivagrans Keifer, and gall makers A. essigi, Aceria brevipunctata (Nalepa) (Michalska 1997) and E. sheldoni (Sternlicht and Giffiths 1974), spermatophores have been found in groups. In vagrants, spermatophore aggregations were most numerous along the midvein and near the junction of lateral veins with the midvein of leaves (i.e. in sites preferably occupied by the eriophyoids) and consisted of spermatophores deposited by different males (Oldfield et al. 1970; Michalska 1997; Michalska unpubl.)

Observations on interspecific attraction of spermatophores (Oldfield 1988) have revealed that females of A. fockeui and A. schlechtendali put on each other's hosts, readily accomplished self-insemination from spermatophores of congeneric males. By contrast, females of E. pyri, P. oleivora, A. fockeui and A. schlechtendali did not visit spermatophores deposited by males of the different genera. Interestingly, E. pyri (whose host plant, similar to A. fockeui and A. schelchtendali, belongs to Rosaceae) showed some interest in spermatophores of the Aculus species.

Spermatophore deposition rate and strategic ejaculation

Exempt from costly mating behaviours, males of sex-dissociated species need to produce numerous spermatophores to increase their presence for random, 'independent' females (Thomas and Zeh 1984; Proctor 1998). Indeed, in many sex-dissociated arthropods the rate of spermatophore deposition can be high (Proctor 1998). The extreme examples are water mites, in which hundreds of spermatophores per day can be produced. In eriophyoids, such as in other terrestrial prostigmatic mites, the spermatophore production is much lower. In isolation, A. fockeui males deposited on average 30 spermatophores per day, males of $P$. oleivora deposited 16 spermatophores per day (Oldfield et al. 1970) while A. sheldoni (Sternlicht and Goldenberg 1971) and A. allotrichus (Michalska, unpubl.) deposited only a few spermatophores per day. 
Several factors can influence spermatophore deposition by eriophyoids. In A. fockeui, the rate of spermatophore placement depended on male age (Oldfield and Newell 1973) and time of the day (Michalska 2005).

In $C$. hendersoni, the host plant and its quality influenced the output of spermatophores. Males deposited much less spermatophores on an older, more lignified yucca leaf than on a young one (Michalska and Shi 2004). Similar inhibition of spermatophore deposition rate has been observed in males placed on young but mechanically injured leaves. Interestingly, on the leaves previously injured by conspecifics the rate of spermatophore deposition increased in comparison with the uninjured and mature (1-3 apical) leaves. This phenomenon may be a result of greater availability of nutrients in injured leaves due to communal feeding of eriophyoids. Moreover, one cannot exclude that the mite injury and/ or substances left by conspecifics on the leaf surface are cues signaling the availability of potential mates, thereby stimulating males to deposit spermatophores (Michalska and Shi 2004).

Sperm competition takes place when two or more ejaculates of different males compete over the fertilization of a given set of eggs. It is regarded as a major selective force that shapes both the ejaculate expenditures across species as well as the strategic ejaculation within species (Parker 1998; Wedell et al. 2002). Pairing males are known to strategically conserve sperm or invest in it depending on the availability of females, their mating status, quality, as well as the presence of rivals. Similarly, in sex dissociated species, e. g. some water mites, males increase or decrease spermatophore deposition rate in the presence of rival males and/or spermatophores, or increase it when they are accompanied by females. In others, however, conspecifics did not affect spermatophore deposition (Witte 1991; Proctor 1992).

Stimulation of spermatophore placement by eriophyoid males in the presence of females was observed in $C$. hendersoni (Michalska and Shi 2004). On the yucca leaves previously injured by eriophyoids, a male accompanied by six virgins deposited significantly more spermatophores than a male kept alone. However, on uninjured and mature leaves (on which, as was mentioned above, males of this species are generally reluctant to deposit spermatophores) such a stimulatory effect of virgins was not observed.

In the tests made so far on the effect of rival males on eriophyoid spermatophore deposition, no response or impediment of spermatophore placement in the presence of competitors was noted. $C$. hendersoni males, randomly chosen from a population and put on injured, mite-free yucca leaves did not change the deposition rate either in the presence of other males or their spermatophores (Michalska and Shi 2004). Random males of A. fockeui that were grouped on fresh, uninjured peach leaves behaved similarly (Michalska 2005). However, young males of this eriophyoid, tested in similar conditions, clearly diminished the deposition rate in the presence of rivals (Michalska 2000).

Several factors can be responsible for such interspecific differences in male behaviour. As predicted and confirmed by tests in several pairing species, ejaculate expenditures can depend on the species-specific level of sperm competition, male information about the actual level of sperm competition or alternative mating tactics (Parker 1998; Wedell et al. 2002). In eriophyoid mites, however, male decision about spermatophore deposition on a particular patch may also rely on the probability that any receptive female will seek spermatophores within that patch. On uninjured leaves (such as in the test with A. fockeui), with numerous rivals but without females and without cues left by conspecifics that could indicate the presence of receptive "mates", male chances for female fertilization could be especially low, which might force eriophyoids to conserve sperm (Michalska 2000). The differences in response between populations of mixed-age males and vigorous young males 
of A. fockeui may be connected with the more intensive sperm competition occurring in the latter (Michalska 2005). To clarify this point, however, more studies on the strategic ejaculation of eriophyoid mites including experiments with varying number of rivals and the presence of receptive females are needed.

Male attendance of pre-emergent females and avoidance of external sperm competition

In many insect and mites, males search for females at their emergence sites in order to be the first to mate with them (Walter and Proctor 1999; Thornhill and Alcock 1983). A similar phenomenon has been observed in the eriophyoid mites A. fockeui (Putman 1939; Michalska and Boczek 1991), A. allotrichus, A. essigi (Michalska and Boczek 1991; Michalska and Mańkowski 2006), A. hystrix (Skoracka unpubl.), and Cecidophyopsis ribis (Westwood) (Fenton unpubl.) (after Michalska and Mańkowski 2006). Among them, only A. allotrichus and A. hystrix males exhibited solitary or joint guarding of quiescent female nymphs (QFNs). Aculops allotrichus males attended QFNs for many hours until female emergence, encircling them with spermatophores (Michalska 1999). By contrast, in nonguarding $A$. fockeui and $A$. essigi, male visits of pre-emergent females were usually short and only rarely males deposited spermatophores next to a QFN (Oldfield and Michalska 1996; Michalska and Mańkowski 2006).

Interest of eriophyoid males in QFNs seems to be connected with a single or at most few inseminations in a female's life (Michalska and Mańkowski 2006). In A. fockeui, both young and old virgins pick up sperm from only a single spermatophore (Oldfield and Newell 1973) and always store it asymmetrically in just one of the paired spermathecae (Oldfield 1973). Volumetric comparisons of a sperm-filled spermatheca and a sperm drop of spermatophores of $A$. fockeui and several other eriophyoids from dicots revealed a possible close relationship between the asymmetrical sperm storage and single insemination in these mites (Oldfield 1973).

Interestingly, most species currently known to store sperm asymmetrically originate from dicots, with only one exception of A. hystrix from a monocot (Oldfield 1999). It implies the predominance of male attendance of pre-emergent females on dicotyledonous plants. By contrast, symmetrical sperm storage (in both spermathecae) and multiple inseminations by females appears to be a rule for phytoptids inhabiting all gymnosperm, monocots and dicots as well as eriophyids from monocots (Oldfield 1999). This relationship supports recent observations on multiple visits to spermatophores and symmetrical sperm storage in $C$. hendersoni from yucca, which belongs to monocots (Michalska and Mańkowski 2006).

The asymmetrical sperm storage was also confirmed in guarding A. allotrichus and A. hystrix (Oldfield 1999). As shown by Michalska and Mańkowski (2006), a majority of A. allotrichus females visited just one spermatophore in their lives. Nonetheless, some females mounted two spermatophores suggesting 'incomplete' monoandry in this species. As the presence of sperm in spermathecae was not examined in this study, further investigations are needed to determine whether A. allotrichus females replenish sperm supplies in the sperm sac during the second visit or require a second spermatophore due to unsuccessful insemination from the first spermatophore mounted.

As shown by the observations on A. allotrichus (Michalska 1999) eriophyoid guarding has some special features that make it very different from that of species in which males and females copulate. Firstly, sperm release is shifted to the period of female quiescence, which enables eriophyoid males to monopolize females before their emergence. It may explain why in the absence of rivals, some guarding males of A. allotrichus left QFNs prior 
to their moult, a pattern rarely observed in species that exhibit male-female copulation (Michalska 1999). Secondly, eriophyoid females remain independent of males in picking up sperm from spermatophores deposited nearby. Perhaps, as a consequence, A. allotrichus males did not occupy any special resting position (e.g. on the top of a pre-emergent female as the males that copulate with females, as seen in Tetranychus urticae Koch), which could facilitate quick insemination of the mate (Michalska 1999). However, they spent 30-50\% of the resting time tightly clinging to QFNs, which could reduce rival access to the QFN and spermatophore deposition nearby.

There is a common agreement that in insects, precopulatory guarding is an adaptation to securing a partner for mating rather than to reducing sperm competition after mating (Parker 1970; Simmons 2001). Similarly in non-guarding eriophyoids, deposition of a single spermatophore close to a QFN only increases the chances for its encounter with the emerging female. However, if males defend the nymph and its vicinity they could also avoid external sperm competition. In such a way, defense of spermatophore fields reduces spermatophore competition in some sex-dissociated arthropods (Proctor 1998).

In $A$. allotrichus, the fierce fighting between solitary guarders and intruders can be seen rarely, mostly at low densities (Michalska 1997). At high densities, it often happens that the guarders do not respond to intrusions, remain motionless or only move closer the QFN body. As a result, males frequently guard QFNs jointly, i.e. up to several males around a single nymph (Michalska and Boczek 1991; Michalska 1997). The avoidance of agonistic interactions at male crowding and joint guarding was reported by Potter (1981) for the spider mite, T. urticae. There are also numerous examples of other invertebrates as well as vertebrates in which at high densities of populations, males become less aggressive or nonterritorial (rev. Potter 1981, see also Suhonen et al. 2008). According to Potter (1981), at high densities, the avoidance of aggressive interactions could be evolutionary advantageous for guarding males. Under such conditions, the intensity of rival invasions is increased as well as the probability that a guarder will be defeated. Moreover, if the guarder engages in fighting with an intruder he also risks that at the same time a female (or a preferable position on or close to her) would be 'taken over' by another intruding male.

In A. allotrichus, the activity of joint-guarders is quite different from that of males guarding solitarily. Isolated from the harassment of intruders single males alternately rested, deposited spermatophores, explored the close vicinity of QFNs or fed (Michalska 1999). They did not alter their activity as females approached moulting. On the contrary, males in a group of five spent most of their time being motionless and clumped close to the QFNs (Michalska 1997). The situation changed, however, a few hours before female emergence. During that time, co-guarders intensively explored the vicinity and often engaged themselves in pushing and wrestling with each other. Although the vicinity around QFNs was not blocked, yet spermatophore deposition appeared to be reduced due to more or less aggressive interactions between males (Michalska 1997).

Crushing spermatophores of rivals, breaking them, trampling to the ground or eating them is the method of reducing sperm competition characteristic for non-pairing males of other arthropods (Proctor 1998; Stam et al. 2002). In eriophyoid mites, however, such destructive behaviour has never been noted (Michalska unpubl.).

According to Witte and Döring (1999) destructive behaviour is less expected to occur in species with males that are unable to recognize rival spermatophores and to prevail in species that do not return to places where they previously deposited spermatophores. Also in eriophyoids, destructive behavior might have not evolved because for some reasons these mites are unable to distinguish between spermatophores. One cannot exclude however, other traits of eriophyoids, such as high density of population and relatively low 
spermatophore production (see the section, Spermatophore deposition rate and strategic ejaculation) acting against destructive behaviour as well. In species exhibiting destructive behaviour the greater the density of competitor males is the higher should be the risk that the spermatophore will be found by a rival and destroyed. In a hypothetical, extreme situation, all male's spermatophores could be destroyed before females have a chance to pick up sperm from them. The losses from such destructive behaviour, may be greater at low spermatophore production (at the same rate of spermatophore destruction by rivals a male depositing more spermatophores would have the smaller portion of its spermatophores destroyed at any given time than a male with the lower deposition rate). Thus, at the specific level of population density and spermatophore production, even in species in which males perfectly distinguish between their own and rival spermatophores, destructive behaviour may not be beneficial and selected against.

\section{Eriophyoid mating systems}

The concept of mating systems refers to how males and females of a population can gain access to mates, how many mates they have, how long their bonds last, whether parental care is provided, and if so, by which sex (Shuster and Wade 2003; Danchin et al. 2008). In the sex dissociated arthropods, males and females can interact indirectly, via spermatophores, which can make their mating systems much more complex than in species where males and females pair to mate. For example, Proctor (1998) pointed out that analogous to lekking males that congregate in small arenas and are visited by females for copulation, aggregations of spermatophores can function as leks in sexually dissociated species. Similarly, in eriophyoids, placement of spermatophores into groups with spermatophores of other males (see the section Attraction to spermatophores) can be regarded as lek-like behaviour.

Considering that eriophyoid males produce numerous spermatophores while females pick up sperm from either single (or, in some species at the most two spermatophores) or several spermatophores in their life time (see the section Male attendance of pre-emergent females and avoidance of external sperm competition) two preliminary categories of eriophyoid mating systems could be taken into account: (1) the polygynous mating system (males mate many times and females only once in their lifetime) with female attendance polygyny (males attend individual females, abandon them shortly after mating and continue seeking mates) in one case, and (2) the polygamous mating system (both males and females mate many times) in the alternate case (see Shuster and Wade 2003). Spatiotemporal availability of females, male-male competition and external sperm competition may determine to what degree eriophyoid males will attend pre-emergent females, whether they will deposit spermatophores beside them or form 'leks' of spermatophores. Several species-specific traits can be crucial in respect to this, e.g. the number of self-inseminations by females, sex ratios (Michalska 1999; Michalska and Mańkowski 2006), population density, longevity of sperm in spermatophores, number of spermatophores produced in a male lifetime, and so forth.

\section{Future directions}

As shown above, some important issues concerning sexual behaviour of eriophyoid mites still remain to be elucidated, or studies on them are very preliminary. These concern especially, communication between sexes, female choice, external spermatophore competition and eriophyoid mating systems. 
Knowledge of sex pheromones may have great practical importance for the control of eriophyoid pests in agricultural crops. Behaviour of $A$. fockeui females towards spermatophores, stimulation of spermatophore deposition by $C$. hendersoni virgins and male interest in quiescent female nymphs observed in several species strongly suggest the presence of sex attractants in both eriophyoid spermatophores and in females or quiescent female nymphs. However, only the isolation of such chemicals and their experimental bioassay will confirm sex attractants unambiguously. It would be necessary to determine whether the placement of spermatophores in groups indeed increases their attraction to females; what is the 'calling' distance of eriophyoid attractants; and what other factors may help eriophyoids to find spermatophores (e.g. electrostatic forces) or distinguish the sex of the individual (e.g. differences in size between males and females)?

Female choice by non-pairing females was uncertain (Proctor 1998) until the study by Gols et al. (2004) on the springtail, Orchesella cincta (L.). In the experiment, females were given a choice between spermatophores deposited by two different males. Paternity analysis based on the variation in a microsatellite locus showed that females were selective and picked up sperm from spermatophores of one male only. Previous observations by Hedlund et al. (1990) revealed that the smell of a spermatophore may play a role in $O$. cincta female choice. Do eriophyoid females choose similarly, on the basis of spermatophore odour, or, other spermatophore traits such as contact chemicals, size of a spermatophore and the size of the sperm drop contained in it? In non-choice tests (Oldfield 1988) females picked up sperm from spermatophores of congeneric males of each other's host while they did not visit spermatophores produced by males of different genera. It suggests that eriophyoids are not able to distinguish between spermatophores of their own and closely related species. To verify this hypothesis, pair choice tests performed on the host plant of a female are needed, as well as experiments explaining how relatedness of a host plant of a male to the host plant of the female may interfere in the 'proper' choice of a spermatophore. Such knowledge could be very useful for better understanding of speciation mechanisms in this group of mites.

Sperm competition is one of the fundamental components of sexual selection that for years has been intensively investigated both theoretically and empirically (Danchin et al. 2008). Proctor (1998) pointed out that similar to sperm of external inseminators, the sperm contained in spermatophores of sex dissociated arthropods may compete outside the female's reproductive track. In spite of many reports that support this hypothesis, external spermatophore competition was not investigated in detail. As for eriophyoid mites, we already know that species can differ significantly in spermatophore deposition rates and there is flexibility of spermatophore deposition in the presence of rival males and females. Moreover, there are marked differences among eriophyoids in the degree of female attendance by males. It makes them very suitable objects for comparative studies on external sperm competition and spermatophore expenditures both within and across species.

There are still too few behavioural observations to allow a thorough classification of mating systems of eriophyoid mites. In the future, emphasis should be given to the number of matings by females and males, distribution of females and spermatophores as well as the interactions between and within sexes.

The observations on sperm storage and the number of self-inseminations by females (Oldfield 1999) imply the prevalence of eriophyoid polygyny on dicotyledonous host plants and polygamy on monocots and gymnosperms. It also suggests an impact of a host plant on the evolution of eriophyoid mating systems. In gymnosperms and some angiosperms, including monocotyledonous Poaceae, a gregarious life habit appears to be one of 
the plant adaptations to wind pollination (Culley et al. 2002). Such gregarious life habit of a host plant seems to have a beneficial effect on the aerial dispersal of eriophyids especially for those species with multiple insemination. As was observed in C. hendersoni (Michalska unpublished), polyandrous females visit many spermatophores in their lifetime and have to replenish sperm supplies virtually every day. It means that sooner or later after landing on a new plant such females would be faced with the necessity of finding a spermatophore. However, the more scattered a host there are less chances for females not only to find a host plant but also a host plant with spermatophores on it. Thus, if a host plant is scattered, such as in case of many dicotyledonous plants, it could be more advantageous for eriophyoid females to pick up sperm just once in their lifetime and before migration to a new plant. Obviously, such a strategy also entails the cost of picking up sperm of a bad quality male for the entire female's life. As a consequence, on a gregarious host plant a female performing single insemination could achieve a much lower reproductive success than the polyandrous one and may be selected against. As is shown in the example of A. hystrix from grasses (Oldfield 1973), however, the secondary invasion of a gregarious plant species by an eriophyid in which females accomplish single insemination cannot be excluded. Therefore, to elucidate the possible role of a host plant in the evolution of eriophyoid mating systems more data on mating systems and phylogeny of eriophyoids as well as the ecology of a host plant needs to be collected.

\section{Defence against predators}

Many predaceous insects (dipterans, coleopterans, neuropterans, hemipterans, thysanopterans) and mites (Phytoseiidae, Stigmaeidae, Cheyletidae, Cunaxidae, Tarsonemidae, Tydeidae) have been reported to feed on eriophyoid mites (Perring and Mcmurtry 1996). Among them, phytoseiid and stigmaeid mites are considered the most important enemies of eriophyoids (Sabelis 1996; Thistlewood et al. 1996). In contrast to stigmaeids, phytoseiids are much larger and faster predators and are able to detect eriophyoid mites from a long distance via volatiles emitted by infested plants (Dicke 1988; Dicke et al. 1988; Aratchige et al. 2004). For many of them, however, eriophyoids are an alternative food only (Sabelis 1996; Sabelis and van Rijn 1996) while stigmaeids, in the vast majority, preferably prey upon these mites (Thistlewood et al. 1996). Moreover, being smaller, stigmaeids can more effectively seek eriophyoids within short distances and penetrate their hiding places that may be inaccessible for phytoseiids.

Prey organisms exhibit a variety of morphological, physiological, life-historical and behavioural adaptations that enable them to reduce the chances of being eaten (Sih 1987). Eriophyoid mites are much smaller and slower than insect and mite predators which significantly constrain their fleeing or physical defense upon attack (Sabelis and Bruin 1996). The probable consequence of this is the common use of refuges by these tiny mites. These refuges not only serve as a shelter against predators but can also play an important role in the protection of eriophyoids against adverse abiotic conditions. Refuge-forming eriophyoids induce the growth of galls out of plant tissue or spin web strands on a plant surface and live socially under webbing (Sabelis and Bruin 1996; Sabelis 1996; see also the section on "Social Behaviour"). Others inhabit very narrow spaces, e. g. acarodomatia of leaves or spaces under scales pressed against leaf petioles, sheaths, buds, fruits or bulbs (Sabelis and Bruin 1996; O’Down and Willson 1997; Kasai et al. 2002; Leśna et al. 2004; Romero and Benson 2005; Aratchige et al. 2007; Lawson-Balagbo et al. 2007). Others occupy habitats that are adverse for natural enemies such as A. lycopersici on the tomato 
leaves covered by sticky and toxic trichomes (Sabelis 1996; Koller et al. 2007), or Leipothrix darlingtoniae Fashing hiding inside the pitchers of the insectivorous plant, cobra lily Darlingtonia californica Torr. (Fashing 1994; Fashing NJ, personal communication).

Many observations confirm that refuges of eriophyoid mites are not perfect hiding places from predatory mites. Phytoseiids can creep inside the pouch galls at the time of eriophyoid dispersal, when the galls are drying up and their entrances are opening. Also erinea, felt-like galls, are frequently visited by predatory mites (Sabelis 1996) as well as the 'narrow spaces' used by refuge seekers (Leśna et al. 2004; Aratchige et al. 2007; LawsonBalagbo et al. 2007). Aceria guerreronis lives under the perianth of the coconut fruit. The eriophyoid invades the very young, 1-3 month old fruit when the perianth-fruit gap is too tight for predatory mites. Due to mite damage, however, the gap increases in size and within a month can be entered by phytoseiids (Aratchige et al. 2007; Lawson-Balagbo et al. 2007). It is very likely that such a 'gate opening' for predators is not only a by-product of the damage of plant tissue but may also be an induced plant defense against eriophyoids (Aratchige et al. 2007). This hypothesis is supported by the observations on Aceria tulipae (Keifer) inhabiting the inside of the tulip bulbs. First, the bulbs infested by eriophyoids produce volatiles that attract phytoseiids to them (Aratchige et al. 2004). Second bulb damage triggers the production of ethylene, which causes the widening of the space between scales at the apex of the bulb to such an extent that it becomes penetrable for predatory mites (Leśna et al. 2004).

Vagrants are generally much more vulnerable to predation than the refuge-forming or refuge-seeking eriophyoids. Although they can balance the higher risk of predation by better opportunities to produce offspring on the unconfined and usually, more nutritious plant parts (Sabelis and Bruin 1996) they have also developed various adaptations that can serve as anti-predatory defenses. Hiding in shafts of leaf trichomes by the quiescent stages of Rhinophytoptus concinnus Liro, and Macrotuberculatus bagdasariani (Shevtchenko and Pogosova) on elm (Michalska 2003) and Aculus comatus (Nalepa) on filbert (Krantz 1973) are good examples of this behavioural adaptation. The playback experiment with hungry females of the phytoseiid mite Typhloctonus tiliarum (Qud.) [synonym: Neoseiulella tiliarum (Quademans) (Chant and McMurtry 2007)] and the quiescent nymphs $R$. concinnus proved that by 'perching' on the tips of leaf hairs, the vagrants can avoid phytoseiid attack (Michalska 2003). The predatory females needed much more time to find and consume the nymphs on leaf hairs than the nymphs placed on a leaf blade. The hiding of quiescent stages can be advantageous for eriophyoid mites mainly for two reasons. First, being motionless the mites are unable to escape from predators. Second, by restricting the use of the refuges to only the quiescent period, the vagrant mites have not resigned from or limited their feeding and reproductive activities (Michalska, 2003). Apparently, hiding on leaf trichomes is not solely an eriophyoid 'invention'. In the tetranychid mite, Yezonychus sapporensis Ehara on the dwarf bamboo, quiescent juveniles rest and females lay eggs on tips of hairs (Saito 1985). An experiment with eight species of phytoseiid mites confirmed that the egg-lying behaviour of $Y$. sapporensis has a function of avoiding predation (Yanagida et al. 2001). Interestingly, for another mite, Tetranychus kanzawai Kishida constructing a web over the leaf, it has been proven that juveniles enter the quiescent stage on a leaf or hide in the web according to the actual presence or absence of predatory mites (Oku et al. 2003).

Climbing up a trichome by $R$. conncinnus resulted from a fixed chain of behaviours including: (1) the attachment of the anal sucker to the tip of a hair, (2) pushing back from a leaf or the basal part of a trichome and finally, (3) lifting the body up to become motionless (Fig. 3a). This quite bizarre mode of climbing was preceded by the equally curious 

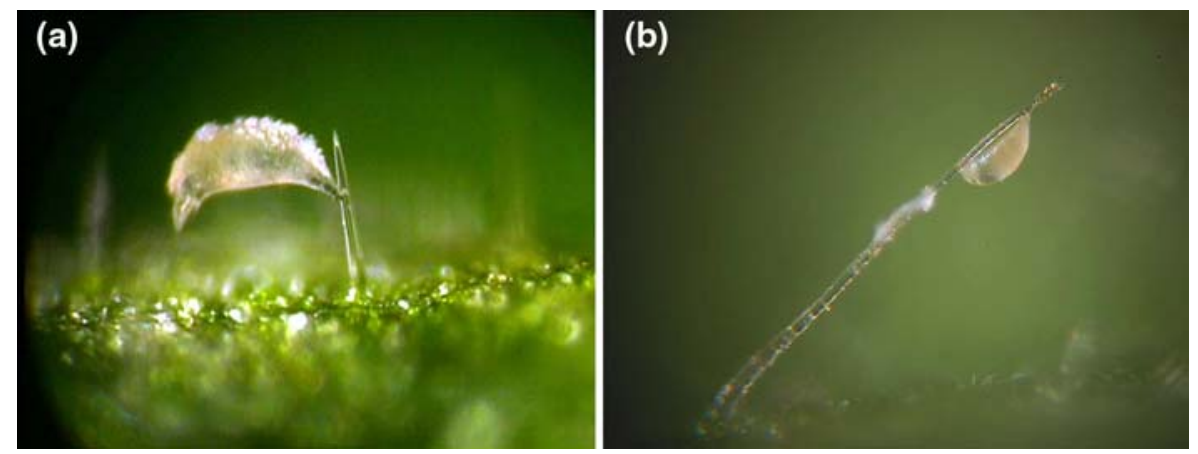

Fig. 3 Quiescent nymphs secured to tips of leaf trichomes: on a Rhinophytoptus concinnus Liro on elm and b Aculus comatus (Nalepa) on filbert (on a trichome, beneath a nymph can be seen the shed exuvium of the previous eriophyid that spent quiescent period and molted on the trichome)

searching behaviour of eriophyoids in a "hand stand" position. The pre-quiescent mites raised the caudal end of their bodies (becoming stiffened prior to the eriophyoid quiescence) and circled in both directions around the leaf blade until they found a suitable hair and attached to it with their anal sucker (Michalska 2003). By contrast, the juveniles of A. comatus went straight up the hair, made a turn on its tip and became motionless attached upside down along the longer axis of the trichome (Fig. 3b) (Krantz 1973; Michalska unpubl.).

These behavioural observations as well as the survey of resting sites of quiescent stages on leaves strongly suggest that hiding upon trichomes by all of the above mentioned eriophyoid species is fixed, i.e. takes place independently of the actual presence of predators (Krantz 1973; Michalska 2003; Michalska unpubl.). It is worth noting that both elm and filbert leaves are rich in domatia, plant structures frequently used by phytoseiids as shelters (Walter 1996; Kreiter et al. 2002; Romero and Benson 2005). The presence of domatia generally favours the occurrence of phytoseiids on leaves. Thus, the threat of predation on elms and filbert should be relatively high and constant which might be an important selective force in the evolution of eriophyoid climbing behaviour and its fixation. Curiously enough, on elms, another leaf vagrant, $R$. ulmivagrans lays eggs and spends the quiescent period exclusively inside domatia (Michalska 2003). As a rule, on leaves inhabited by this mite, the domatia are full of resting stages. It is likely that the eriophyoids inside domatia are preyed upon by phytoseiids. However, the dead bodies of the companions situated close to the entrance of a domatium may hinder predation on individuals lying deeper inside. For comparison, an eriophyoid (unidentified species) inhabiting the domatia of the tropical tree Cupania vernalis Cambess, clogs the entrances of domatia with the "tufts" made of the shed exuvia and a sort of silky material (Romero and Benson 2005). Whether such behaviours of eriophyoid mites could favour their avoidance of predation should be further investigated.

It must be stressed that as in many other communal animals, the tendency of eriophyoid vagrants to aggregate on leaves can be beneficial for them not only to enhance reproduction (see the section "Sexual Behaviour") or resource exploitation but also to enhance escape from predators (e.g. Danchin et al. 2008). In aggregations, an individual can be protected through (1) dilution effect (companions that are alternative prey), (2) selfish herd effect (an individual can hide behind companions), and (3) confusion effect (predators cannot concentrate on a single prey when other prey are moving). 
In eriophyoid vagrants, one cannot exclude physiological adaptations against predators, such as prey toxicity or unpalatability (Sabelis 1996). Waxy or liquid coatings produced by some eriophyoids (Manson and Gerson 1996) may protect them against desiccation only, or they also make them less detectable or distasteful for predators; this question remains to be resolved and can be a subject for future research. And finally, do eriophyoids accumulate toxins from their host plants? The phytoseiid Amblyseius victoriensis (Womersley) [synonym: Euseius victoriensis (Womersley) (Chant and McMurtry 2007)] drastically diminished the rate of prey attacks when fed on the eriophyoid mite A. lycopersici from tomato in the comparison with other eriophyoid species (James 1989). Although its contact with toxic glandular trichomes of tomato leaves could negatively affect the hunting efficacy of this predator and also be responsible for its high mortality during the experiment (Sabelis 1996), the distastefulness and toxicity of A. lycopersici as a prey cannot be excluded. The accumulation of toxic plant compounds was recently found in another herbivorous mite from tomato, Tetranychus evansi Baker and Pritchard. The consumption of this herbivore by the phytoseiid Neoseiulus californicus (McGregor) negatively affected the developmental time and oviposition rate of the predator, to the similar extent as the adverse effect of the tomato plants. Interestingly, neither the plant nor the prey had any impact causing an increase in the mortality of this phytoseiid (Koller et al. 2007).

Future directions

The data are still lacking on the flexibility of antipredatory behaviour in eriophyoid mites. It is urgently needed to examine whether these mites, perhaps similar to tetranychids (Grostal and Dicke 2000) could assess the risk of predation using direct (dead bodies of companions) or indirect cues (faeces of predators fed on eriophyoids or other herbivores). Do the eriophyoids make a decision about refuge use or dispersal in relation to the presence of predators or their cues? How does the threat of predation affect the eriophyoid activities such as feeding or reproduction?

The observations on the genus Stigmaeopsis Banks (Mori and Saito 2004), living socially under a web have revealed that tetranychid mites can effectively defend the nest against the youngest stages of predatory mites through counterattack. Moreover, the more individuals per nest the better effect of 'nest defense' in this spider mite genus. Undoubtedly, solitary eriophyoids would lose in the confrontation with the much bigger and faster predatory mites. However, are eriophyoids equally defenseless in social groups? Social web-nests of Aceria inusitata Britto and Navia, for example, can contain more than one hundred individuals (Britto et al. 2008, see also the section on "Social Behaviour"). Could this eriophyoid adopt an anti-intruder strategy such as mass counterattack?

\section{Social behaviour}

Social organization among invertebrates is classified, according to its complexity, into eusociality or presociality (Wilson 1971). Eusocial organisms exhibit: division of labour, possibly with some sterile castes; overlapping of generations, such that different generations live in the same colony; and cooperation of individuals to care for immature forms. Presocial organisms can display some of these behaviours, but they do not display all three essential traits of eusociality. Presocial organisms can be further categorized into "subsocial", in which parents interact with immature forms, and "parasocial", in which 
individuals of the same generation live in a cooperative system. Mites, for all presently known examples of social behaviour, can be classified as subsocial (Saito 1997).

Among phytophagous mites sociality has been reported and detailed for the woven nestbuilding mites of the genus Stigmaeopsis. These mites build dense oval woven roofs (webnests) over depressions on the lower surfaces of host leaves and have been considered as subsocial or communal species (Saito 1995; Mori and Saito 2006). Stigmaeopsis celarius Banks exhibits biparental care, in a way that adult males and females can defend their nest and offspring from phytoseiid predators (Saito 1986). Stigmaeopsis longus (Saito) females share reproduction and labour evenly with their nest mates (Mori and Saito 2006). It has also been observed in Stigmaeopsis miscanthi (Saito) that members cooperate in nest building and sanitation activities (Sato et al. 2003). Saito (1997) listed six main factors affecting social organization in Acari: (1) male-haploidy and thelytoky, (2) low mobility, with 1 and 2 both favouring high relatedness; (3) continuous iteroparity and rapid development, allowing generation overlapping; (4) aggregation, increasing probability of sib interactions; (5) prevention of predation and nest building, requiring cooperative labour; (6) spatiotemporally stable environment, that can allow a longer lifetime, aggregation and also generation overlap. One of the ecological prerequisites of social organization of mites is a stable habitat with sufficient resources to enable mites to overlap generations. It is enhanced in some groups, such as spider mite species, under stable environmental conditions that allow them to survive longer in a given place (Saito 1986, 1997). The degree of aggregation is also important for social organization. Nest formation by webs probably evolved as a refuge from predators and shelter from adverse climatic conditions in a stable habitat, and it has simultaneously enhanced aggregation of individuals in a narrow space. Moreover, the period of time that a nest remains functional may be related to the number of individuals living on it and the amount of enclosed resources. Another factor that appears to be responsible for the extent of mite social evolution is the existence of labour that can be shared among individuals. In spider mites there is little labour that can be engaged in by different individuals, so there appears to be little opportunity for selection for division of labour in this group (Saito 1997).

Considerations concerning evolution of sociality in spider mites certainly could be extended to other phytophagous mites, such as eriophyoids. Regarding the conditions or factors affecting social behaviour presented by Saito (1997), it may be possible to show that some eriophyoid species exhibit or develop under conditions that promote sociality. The possibility of sociality in eriophyoid mites was first mentioned by Saito (1997) who suggested that the highly communal way of life of some species, especially gall eriophyoids, combined with male haploidy should have led to social interactions between individuals, if there were a possibility for selection for division of labour. However, so far, no behavioural studies have been conducted on eriophyoid social behaviour.

Searching for the occurrence of social behaviour in eriophyoids should be undertaken, especially considering that communal aggregation is an important factor. Signs of social behaviour should first be investigated in web spinning eriophyoid mites that build colonies under webs, similar to Stigmaeopsis social mites. In this way evidence for social behaviour in eriophyoids can be sought for A. inusitata, a deuterogynous species associated with Caesalpinia echinata Lam. from Brazil, colonies of which develop under "patches of webbing" (Fig. 4). For the most part, deuterogyny is primarily an evolutionary adaptation of eriophyoid mites for survival on deciduous plants in regions with well-defined winters, thus presenting alternation of life forms to survive different seasons. However, there are some reports of deuterogynous species in tropical areas; so far all examples belong to the genus Aceria (Britto et al. 2008). Among studied deuterogynous species occurring in 

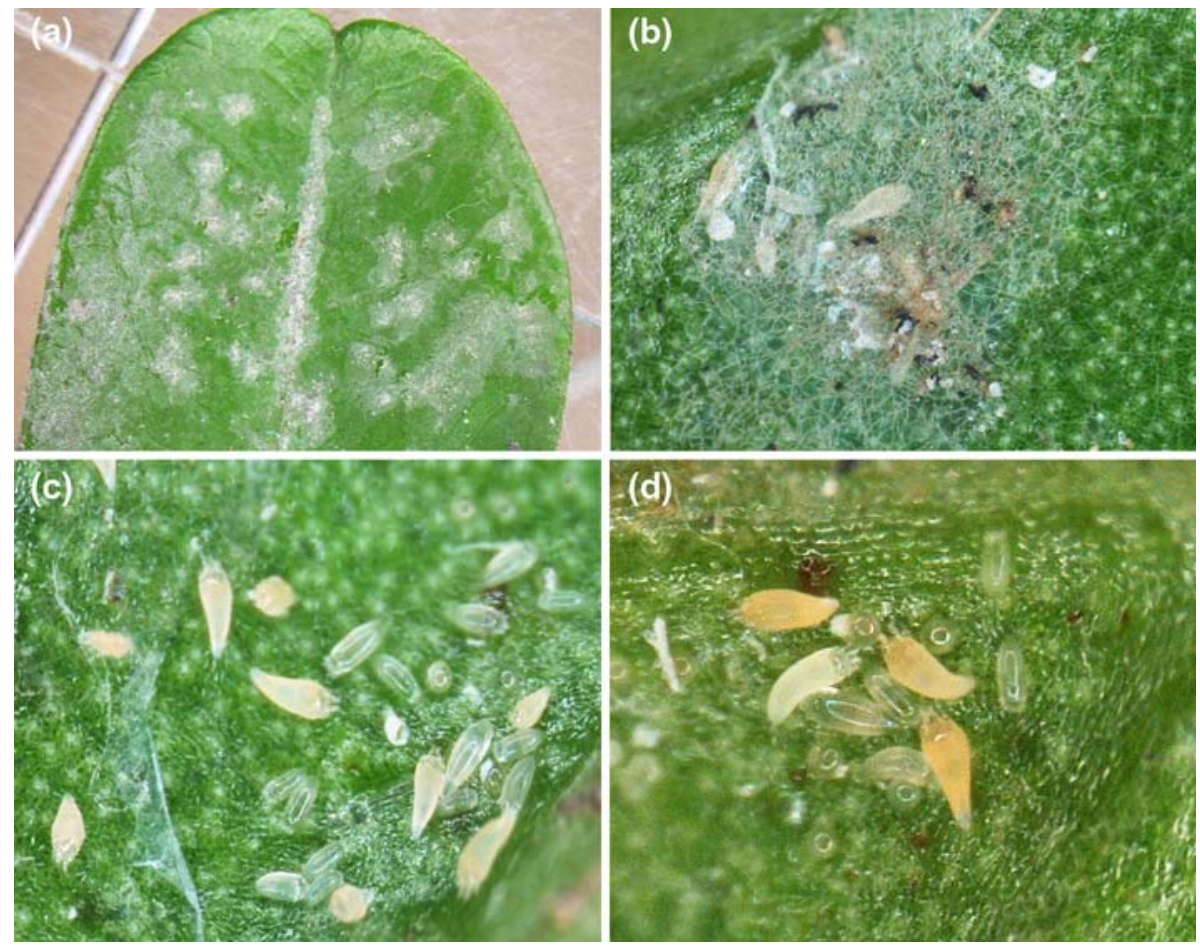

Fig. 4 Colonies of the deuterogynous web spinning eriophyoid mite, Aceria inusitata Britto and Navia, on Caesalpinia echinata leaves; a general aspect of "patches of webbing" on the upper leaf surface; b small colony isolated under a "nest-web"; $\mathbf{c}$ group of individuals after web removal; $\mathbf{d}$ coexisting protogynes and deutogynes (in the photograph, whitish and yellowish individuals, respectively) (photos by E. Britto and D. Navia 2007)

tropical areas, A. inusitata is a rare case, with a complex life cycle. This species presents two forms of females and two of males coexisting and developing in the same colony and in the same "nest" (Britto et al. 2008). Biological observations on A. inusitata suggested that more than one generation cohabit in the same "nest". Only deutogynes built the "nests" and afterwards the protogynes appeared in the colony. Large colonies, reaching $3.2 \mathrm{~mm}^{2}$, can harbour more than 150 individuals. When the nests were removed, $100 \%$ mortality of protogynes and $25 \%$ of deutogynes was observed, and the surviving deutogynes rebuilt the "nest". This suggests that deutogynes are the dispersal form of the species and the "nest" makers; this conclusion is supported by the absence of glandular structures in the protogyne opisthosoma. Biological observations on A. inusitata indicate that the species presents overlapping generations and a division of labour. Thus it could be classified as a "parasocial" species. Behavioural studies should be conduced to better understand sociality in this species.

Future directions

Social behaviour of eriophyoid mites is an unexploited field that may be useful to better understand their phylogeny and evolution. Genetic, biological and ecological 
characteristics of some groups of eriophyoid mites are extremely favourable for the development of sociality, and include male-haploidy, low mobility, iteroparity, gregarious life style, overlap of generations and development under a stable environment. Evidence of social behaviour in the deuterogynous web spinning species $A$. inusitata should be studied in greater detail. In the same way, sociality among other gregarious species, especially gall or erinea-making species, should be investigated.

\section{Other perspectives for behavioural studies on eriophyoid mites}

In addition to the needs and directions indicated in the sections above, there are several important behavioural issues that still need investigation in eriophyoid mites. Parental care, a fundamental issue in behavioural ecology which is indispensable for the recognition of mating systems and social behaviour, is an almost untouched topic. Caring for offspring is the rule for refuge-forming eriophyoids. A fertile female inducing gall growth or building a nest provides a shelter not only for herself but also for her progeny. Do vagrant species care for their progeny? Does the laying of eggs in communal batches by $C$. hendersoni (Michalska and Shi 2004) or concealing eggs in domatia by R. ulmivagrans (Michalska 2003) represent a form of parental care? If so, how common are such behaviours among the free-living species? Also, it may be worthwhile to inquire into how the evolution of these behaviours was influenced by the respective host plants and the presence of some specific plant structures (e.g. domatia, leaf trichomes).

Internal mechanisms responsible for how eriophyoid behaviour is elicited and coordinated still await recognition and investigation. It should include studies on (1) sensory and central nervous systems as well as neural processes expressing different behaviours of eriophyoids; (2) chemicals which control processes such as moulting, mating, aggregating and dispersal; (3) genetic basis of eriophyoid behavior. Only the knowledge on the internal mechanisms enables us to fully understand the effect of external factors on the behaviour and its evolution (Alcock 2001).

Acknowledgments We thank Professor Marek W. Kozłowski at Warsaw University of Life Science, Professor David Orwin at University of Bedfordshire, and two anonymous reviewers for helpful and valuable remarks on the manuscript. The study was partially supported by the Polish Ministry of Science and Higher Education (grant no. 3P04C03825, grant no. 2P04C02530). To CNPq (Conselho Nacional de Desenvolvimento Científico e Tecnológico), Brazil, for the productivity fellowship conceded to the third author.

\section{References}

Alcock J (2001) Animal behavior. An evolutionary approach, 7th edn. Sinauer Associates, Sunderland, Massachusetts, p 543

Alexander RD (1964) The evolution of mating behaviour in arthropods. Symp Royal Entomol Soc Lond 2:78-94

Aratchige NS, Leśna I, Sabelis MW (2004) Below-ground plant parts emit herbivore-induced volatiles: olfactory responses of a predatory mite to tulip bulbs infested by rust mite. Exp Appl Acarol 43:97-107

Aratchige NS, Sabelis MW, Leśna I (2007) Plant structural changes due to herbivory: do changes in Aceriainfested coconut fruits allow predatory mites to move under the perianth? Exp Appl Acarol 43:97-107

Barke HE, Davis R, Hunter PE (1972) Studies on peach silvermite, Aculus cornutus (Acarina:Eriophyoidea). J Georgia Ent Soc 7:171-178

Batchelor GS (1952) The eriophyoid mites of the state of Washington. Wash Agr Exp Sta Tech Bull 6:1-32

Behrens E (1964) Zur biologie und okologie der johannisbeergallmilbe Eriophyes ribis Nal. Sowie ihrer bekampfung in johannisbeerenaubaugebiet perleberg. Bez Schwerin Wiss Z Univ Rostock, Math-Nat 13:279-288 
Bergh JC (1992) Monitoring the emergence and behaviour of pear rust mite (Acarina: Eriophyidae) deutogynes using sticky-band traps. J Econ Entomol 85:1754-1761

Bergh JC (2001) Ecology and aerobiology of dispersing citrus rust mites (Acari: Eriophyidae) in central Florida. Environ Entomol 30:318-326

Bergh JC, Judd GJR (1993) Degree-day model for predicting emergence of pear rust mite (Acari: Eriophyidae) deutogynes from overwintering sites. Environ Entomol 22:1325-1332

Bergh JC, McCoy CW (1997) Aerial dispersal of citrus rust mite (Acari: Eriophyidae) from Florida citrus groves. Environ Entomol 26:256-264

Bergh JC, Smith AH Jr (2001) Ecology and aerobiology of dispersing citrus rust mites (Acari: Eriophyidae) in central Florida. Environ Entomol 30(2):318-326

Bergh JC, Weiss CR (1993) Pear rust mite, Epitrimerus pyri (Acari: Eriophyidae) oviposition and nymphal development on Pyrus and non-Pyrus hosts. Exp Appl Acarol 17:215-224

Bernays EA, Chapman RF (1994) Host-plant selection by phytophagous insects. Chapman \& Hall, New York

Brey CW (1998) Epidemiology of wheat curl mite (Aceria tosichella K.) and wheat streak mosaic virus on feral grass species and effect of glyphosate on wheat curl mite dispersal. Ph.D. Dissertation, Montana State University, Bozeman, 139pp

Britto EPJ, Gondim MG Jr, Navia D, Flechtmann CHW (2008) A new deuterogynous mite (Acari: Eriophyoidae) with dimorphic males from Caesalpinia echinata (Caesalpiniaceae) from Brazil: description and biological observations. Int J Acarol 34(3):307-316

Burgess JE, Thompson MM (1985) Shoot development and bud mite infestation in hazelnut (Corylus avellana). Ann Appl Biol 107:397-408

Chakrabarti S, Chakrabarti S (2005) Population dynamics and diurnal activity of Acalitus hibisci Mondal and Chakrabarti (Acari: Eriophyoidea). Acarologia 45:183-188

Chant DA, McMurtry JA (2007) Illustrated keys and diagnoses for the genera and subgenera of the Phytoseiidae of the world (Acari: Mesostigmata). Indira Publishing House

Chen H, Xu N, Chen Z (2000) On the relationship between content of free amino acid in tea shoot and resistance of tea tree to tea pink mite Acaphylla theae Watt. Acta Phytoph Sin 27:338-342

Courtney SP, Chen GK, Gardner A (1989) A general model for individual host selection. Oikos 55: 55-65

Cromroy HL (1983) Potential use of mites in biological control of terrestial and aquatic weeds. In: Hoy MA, Cunningham G, Knutson L (eds) Biological control of pests by mites. Div. Agriculture and natural Resources. University of California, Berkeley, California, USA, pp 61-66

Culley TM, Weller SG, Sakai KA (2002) The evolution of wind pollination in angiosperms. Trends Ecol Evol 17:361-369

Danchin E, Giraldeau LA, Cézilly F (2008) Behavioural ecology. Oxford University Press, Oxford, p 874

Davies JT, Allen GR, Williams MA (2001) Intraplant distribution of Acalitus essigi (Acari: Eriophyoidea) on blackberries (Rubus fruticosus agg.). Exp Appl Acarol 25:625-639

Davis R (1964) Autoecological studies of Rhynacus breitlowi Davis (Acarina: Eriophyoidae). Fla Entomol 47:113-121

Dicke M (1988) Prey preference of the phytoseid mite Typhlodromus pyri: 1 . Response to volatile kairomone. Exp Appl Acarol 4:1-13

Dicke M, Sabelis MW, de Jong M (1988) Analysis of prey preference in phytoseid mites using an olfactometer, predation models and electrophoresis. Exp Appl Acarol 5:225-241

Duffner K, Schruft G, Guggenheim R (2001) Passive dispersal of the grape rust mite Calepitrimerus vitis Nalepa 1905 (Acari: Eriophyoidea) in vineyards. J Pest Sci 74:1-6

Easterbrook MA (1978) The life history and bionomics of Epitrimerus pyri (Acarina: Eriophyoidae) on pear. Ann Appl Biol 88:13-22

Easterbrook MA (1979) The life history of the eriophyoid mite Aculus schlechtendali on apple in southeast England. Ann Appl Biol 91:287-296

Fashing NJ (1994) A new species of Leipothrix (Prostigmata: Eriophyoidae) form the cobra lily, Darlingtonia californica (Sarraceniaceae). Int J Acarol 20:99-101

Frost WE (1997) Polyphenic wax production in Abaracus hystrix (Acari: Eriophyoidae), and implications for migratory fitness. Physiol Entomol 22:37-46

Gabi G, Mészáros Z (2003) Examination of the development of the deutogynes of Calepitrimerus vitis Nalepa in the vine-growing region of Szekszárd, Hungary (Acari: Eriophyoidae). Acta Phytop Entomol Hung 38:369-376

Gibson RW (1974) Studies on the feeding behaviour of the eriophyoid mite Abacarus hystrix, a vector of grass viruses. Ann Appl Biol 78:213-217 
Gibson WW, Painter RH (1957) Transportation by aphids of the wheat curl mite, Aceria tulipae (K.), a vector of the wheat streak mosaic virus. J Kansas Entomol Soc 30:147-153

Gols R, Ernsting G, van Straalen NM (2004) Paternity analysis in a hexapod (Orchesella cincta; Collembola) with indirect sperm transfer. J Insect Behav 17:317-328

Grahl A, Leuprecht B (1998) Untersuchungen zur Biologie der Tomatenrostmilbe Aculus lycopersici undihrer biologischen Bekämpfung. Mitt. Dt Phytomed Ges 28:41-42

Griffith R (1984) The problem of the coconut mite, Eriophyes guerreronis (Keifer), in the coconut groves of Trinidad and Tobago. In: Webb R, Knausenberger W, Yntema L (eds) Proceedings of the 20th annual meeting of the Caribbean food crops society, St. Croix, U.S. Virgin Islands, Oct 21-26 1984. East. Caribbean Cent., Coll. Virgin Islands \& Caribbean Food Crops Soc., pp 128-132

Grostal P, Dicke M (2000) Recognising one's enemies: a functional approach to risk assessment by prey. Behav Ecol Sociobiol 47:258-264

Hanson AJ (1933) The blackberry mite and its control. State College of Washington Agricultural Experiment Station Bulletin, vol 279, 20pp

Harvey TL, Martin TJ (1980) Effects of wheat pubescence on infestations of wheat curl mite and incidence of wheat streak mosaic. J Econ Entomol 73:225-227

Harvey TL, Martin TJ (1988) Sticky tape method to measure cultivar effect on wheat curl mite population in wheat spikes. J Econ Entomol 81:731-734

Harvey TL, Martin TJ, Seifers DL (1990) Wheat curl mite and wheat streak mosaic in moderate trichome density wheat cultivars. Crop Sci 30:534-536

Hedlund K, Ek H, Gunarsson T, Svegborn C (1990) Mate choice and male competition in Orchesella cincta (Collembolla). Experientia 46:524-526

Herbert HJ (1979) Population trends and behaviour of the pear rust mite, Epitrimerus pyri (Prostigmata: Eriophyoidea), on pears in Nova Scotia. Can Entomol 111:955-957

Jaenike J (1990) Host specialization in phytophagous insects. Annu Rev Ecol Syst 21:237-243

James DG (1989) Influence of diet on the development, survival and oviposition in an Australian phytoseiid, Amblyseius victoriensis (Acari: Phytoseiidae). Exp Appl Acarol 6:1-10

Jeppson LR, Keifer HH, Baker EW (1975) Mites injurious to economic plants. University of California press, Berkeley, Los Angeles, London, p 528

Julia JF, Mariau D (1979) Nouvelles recherché en Cote d'Ivoire sur Eriophyes guerreronis K., acarien ravageur des noix du cocotier. Oleagineux 34:181-189

Kadono F, Fujishiro H, Shiina M, Fujiie A (1982) Seasonal population trends of the Japanese pear rust mite, Eriophyes chibaensis Kadono (Acarina: Eriophyoidae) on pear trees in Chiba. Jap J Appl Entomol Zool 26:213-217

Kasai A, Yano S, Takafuji A (2002) Density of the eriophyoid mites inhabiting the domatia of Cinnamomum camphora Linn. affects the density of the predatory mite, Ambyseius sojaensis Ehara (Acari; Phytoseiidae), not inhabiting the domatia. Appl Entomol Zool 37:617-619

Koller M, Knapp M, Schausberger P (2007) Direct and indirect adverse effects of tomato on the predatory mite Neoseiulus californicus feeding on the spider mite Tetranychus evansi. Entomol Exp Appl $125: 297-305$

Kozłowski J (1995) The acceptance of leaves of various apple varieties by the apple rust mite-Aculus schlechtendali (Nal.). Rocz Nauk Rol E, Ochr Rośl 24:39-44

Kozłowski J, Boczek J (1987) Density and host plants of the apple rust mite-Aculus schlechtendali (Nal.) (Acarina: Eriophyoidea). Pr Nauk Inst Ochr Rośl 29:39-50

Krantz GW (1973) Observation on the morphology and behaviour of the filbert rust mite Aculus comatus (Prostigmata: Eriophyoidea) in Oregon. Ann Entomol Soc Am 66:706-717

Kreiter S, Tixter MS, Croft BA, Auger P, Barret D (2002) Plants and leaf characteristics influencing the predaceous mite Kampimodromus aberrans (Acari: Phytoseiidae) in habitats surrounding vineyards. Environ Entomol 31:648-660

Lall BS, Rahman MF (1975) Studies on the bionomics and control of the erinose mite Eriophyes litchi Keifer (Acarina: Eriophyiidae). Pesticides 9:49-54

Lawson-Balagbo LM, Gondim MGC Jr, de Moraes GJ, Hanna R, Schausberger P (2007) Refuge use by the coconut mite Aceria guerreronis: fine scale distribution and association with other mites under perianth. Biol Control 43:102-110

Leśna I, Conijn CGM, Sabelis MW (2004) From biological control to biological insight: rust-mite induced change in bulb morphology, a new mode of indirect plant defense? Phytophaga 14:285-291

Lindquist EE (1996) External anatomy and notation of structures. In: Lindquist EE, Sabelis MW, Bruin J (eds) Eriophyoid mites-their biology, natural enemies and control. Elsevier Science Publishing, Amsterdam, The Netherlands, World Crop Pests, vol 6, pp 1-30

Lindquist E (1998) Evolution of phytophagy in trombidiform mites. Exp Appl Acarol 22:81-100 
Lindquist EE, Oldfield GN (1996) Evolution of eriophyoid mites in relation to their host plants. In: Lindquist EE, Sabelis MW, Bruin J (eds) Eriophyoid mites-their biology, natural enemies and control. Elsevier Science Publishing, Amsterdam, The Netherlands, World Crop Pests, vol 6, pp 277-300

Lindquist EE, Sabelis MW, Bruin J (1996) Eriophyoid mites their biology, natural enemies and control. Elsevier. World Crop Pests, 6, 822pp

Liu J, Lee EA, Sears MK, Schaafsma AW (2005) Wheat curl mite (Acari: Eriophyoidae) dispersal and its relationship with kernel red streaking in maize. J Econ Entomol 98:1580-1586

MacArthur RH, Pianka ER (1966) On the optimal use of a patchy environment. Am Nat 100:603-609

Manson DCM, Gerson U (1996) Web spinning, wax secretion and liquid secretion by eriophyoid mites. In: Lindquist EE, Sabelis MW, Bruin J (eds) Eriophyoid mites-their biology, natural enemies and control. Elsevier Science Publishing, Amsterdam, The Netherlands, World Crop Pests, vol 6, pp 251-258

Massee AM (1928) The life history of the black currant gall mite, Eriophyes ribis (Westwood). Nat Bull Entomol Res 18:277-307

McCoy CW (1979) Migration and development of citrus rust mite on the spring flush of Valencia orange. Proc Fla State Hortic Soc 92:48-51

McCoy CW, Albrigo LG (1975) Feeding injury to the orange caused by the citrus rust mite, Phyllocoptruta oleivora (Prostigmata: Eriophyoidea). Ann Entomol Soc Am 68:289-297

Michalska K (1997) Reproductive behaviour of some species of eriophyoid mites. Ph.D. Thesis, Warsaw University of Life Sciences, p 85

Michalska K (1999) Spermatophore deposition and guarding in the free-living eriophyid mite Vasates robiniae (Acari). Behaviour 136:899-918

Michalska K (2000) The influence of conspecific males on spermatophore deposition in the eriophyoid mite Aculus fockeui. Exp Appl Acarol 24:905-911

Michalska K (2003) Climbing of leaf trichomes by eriophyoid mites impedes their location by predators. J Insect Behav 16:833-844

Michalska K (2005) Spermatophore deposition throughout the day by the plum rust mite, Aculus fockeui. Exp Appl Acarol 35:111-116

Michalska K, Boczek J (1991) Sexual behaviour of males attracted to quiescent deutonymphs in the Eriophyoidea (Acari). In: Dusbabek F, Bukva V (eds) Modern acarology, vol 2. Academia, Prague, pp 549-553

Michalska K, Mańkowski DR (2006) Population sex ratio in three species of eriophyoid mites differing in degree of sex dissociation. Biological Lett 43:197-207

Michalska K, Shi A (2004) A first view on factors influencing spermatophore deposition by the eriophyoid mite Cecidophyopsis hendersoni (Keifer). Phytophaga 14:141-148

Mishra CS (1912) Litchi leafcurl. Agric J India 7:286-923

Moore D, Alexander L (1987) Aspects of migration and colonization of the coconut palm by the coconut mite, Eriophyes guerreronis (Keifer) (Acari: Eriophyoidae). Bull Ent Res 77:641-650

Moore D, Howard FW (1996) Coconuts. In: Lindquist EE, Sabelis MW, Bruin J (eds) Eriophyoid mitestheir biology, natural enemies and control. Elsevier Science Publishing, Amsterdam, The Netherlands, World Crop Pests, vol 6, pp 561-570

Mori K, Saito Y (2004) Variation in social behaviour within a spider mite genus, Stigmaeopsis (Acari: Tetranychidae). Behav Ecol 16:232-238

Mori K, Saito K (2006) Communal relationship in a social spider mite, Stigmaeopsis longus (Acari: Tetranychidae): an equal share of labor and reproduction between nest mates. Ethology 112:134-142

Mumcuoglu Y, Six E (1974) Milben in der luft. Rev Suisse Zool 81:673-677

Nault LR, Styer WE (1969) The dispersal of Aceria tulipae and three other grass-infesting eriophyoid mites in Ohio. Ann Entomol Soc Am 62:1446-1455

Navia D, De Moraes GJ, Roderick G, Navajas M (2005) The invasive coconut mite Aceria guerreronis (Acari: Eriophyoidae): origin and invasion sources inferred from mitochondrial (16S) and nuclear (ITS) sequences. Bull Entomol Res 95(6):505-516

Nuzzaci G (1976) [Behaviour of eriophyoid mites during the uptake of food]. Entomologica, Bari 12:75-80 (in Italian)

O'Down JD, Willson MF (1997) Leaf domatia and the distribution and abundance of foliar mites in broadleaf deciduous forest in Wisconsin. Am Midl Nat 137:337-348

Oganezova GG, Pogosova AR (1994) On the ecology of Eriophyes armeniacus (Acariformes, Tetrapodili) on Prunus divaricata. Zool Zh 73:28-32

Oku K, Yano S, Takfuji A (2003) Spider mite's use of refuges during the quiescent stage in the presence of a predator. Entomol Exp Appl 108:71-74

Oldfield GN (1969) The biology and morphology of Eriophyes emarginatae, a prunus finger gall mite and notes on A. prunidemissae. Ann Entomol Soc Am 62:269-277 
Oldfield GN (1973) Sperm storage in female Eriophyidae (Acarina). Ann Entomol Soc Am 66:1089-1092

Oldfield GN (1988) Observations on intraspecific attraction to spermathophores by species of Eriophyoidae. In: Channa-Basavanna GP CA, Viraktamath CA (eds) Progress in acalogy. Oxford \& IBH Publ, New Delhi, India, pp 249-253

Oldfield GN (1996) Diversity and host plant specifity. In: Lindquist EE, Sabelis MW, Bruin J (eds) Eriophyoid mites-their biology, natural enemies and control. Elsevier Science Publishing, Amsterdam, The Netherlands, World Crop Pests, vol 6, pp 199-216

Oldfield GN (1999) Distribution of asymmetrical and symmetrical sperm storage in the Eriophyoidea and its phylogenetic implications. In: Bruin J, Geest LPS, Sabelis MW (eds) Ecology and evolution of the Acari. Kluwer Academic Publishers, Dordrecht, pp 157-161

Oldfield GN, Michalska K (1996) Spermatophore deposition, mating behaviour and population mating structure. In: Lindquist EE, Sabelis MW, Bruin J (eds) Eriophyoid mites: their biology, natural enemies and control. Elsevier Science Publishing, Amsterdam, The Netherlands, World Crop Pests, vol 6, pp $185-198$

Oldfield GN, Newell IM (1973) The role of the spermatophore in the reproductive biology of protogynes of Aculus cornutus (Acarina : Eriophyoidae). Ann Entomol Soc Am 66:160-163

Oldfield GN, Hobza RF, Wilson NS (1970) Discovery and characterization of spermatophores in the Eriophyoidea (Acari). Ann Entomol Soc Am 63:520-526

Oldfield GN, Newell IM, Reed DK (1972) Insemination of protogynes of Aculus cornutus from spermatophores and description of the sperm cell. Ann Entomol Soc Am 65:1080-1084

Ozman SK, Goolsby JA (2005) Biology and phenology of the eriophyoid mite, Floracarus perrepae, on its native host in Australia, old world climbing fern, Lygodium microphyllum. Exp Appl Acarol 35(3):197-213

Pady SM (1955) The occurrence of the vector of the wheat streak mosaic, Aceria tulipae, on slides exposed in the air. Plant Dis Rep 39:296-297

Painter RH, Schesser JH (1954) Western wheat grass, an oversummering host of Aceria tulipae (K.), vector of streak-mosaic of wheat. J Kansas Entomol Soc 27:118-119

Parker GA (1970) Sperm competition and its evolutionary consequences in the insects. Biol Rev 45:525-567

Parker GA (1998) Sperm competition and the evolution of ejaculates: towards a theory base. In: Birkhead TR, Moller AP (eds) Sperm competition and sexual selection. Academic Press, San Diego, California, pp 3-54

Perring TM, McMurtry J (1996) Other predatory arthropods. In: Lindquist EE, Sabelis MW, Bruin J (eds) Eriophyoid mites-their biology, natural enemies and control. Elsevier Science Publishing, Amsterdam, The Netherlands, World Crop Pests, vol 6, pp 471-479

Proctor HC (1992) Mating and spermatophore morphology of water mites (Acari: Parasitengona). Zool J Linnean Soc 106:341-384

Proctor HC (1998) Indirect sperm transfer in arthropods: behavioural and evolutionary trends. Annu Rev Entomol 43:153-174

Putman WL (1939) The plum nursery mite (Phyllocoptes fockeui Nal. And Trt.). Ann Rev Entomol Soc Am $55: 431-435$

Romero GQ, Benson WW (2005) Biotic interactions of mites, plants and leaf domatia. Curr Opin Plant Biol 8:436-440

Sabelis MW (1996) Phytoseiidae. In: Lindquist EE, Sabelis MW, Bruin J (eds) Eriophyoid mites-their biology, natural enemies and control. Elsevier Science Publishing, Amsterdam, The Netherlands, World Crop Pests, vol 6, pp 427-456

Sabelis MW, Bruin J (1996) Evolutionary ecology: life history patterns, food plant choice and dispersal. In: Lindquist EE, Sabelis MW, Bruin J (eds) Eriophyoid mites-their biology, natural enemies and control. Elsevier Science Publishing, Amsterdam, The Netherlands, World Crop Pests, vol 6, pp 329366

Sabelis MW, van Rijn PCJ (1996) Eriophyoid mites as alternative prey. In: Lindquist EE, Sabelis MW, Bruin J (eds) Eriophyoid mites - their biology, natural enemies and control. Elsevier Science Publishing, Amsterdam, The Netherlands, World Crop Pests, vol 6, pp 757-764

Saito Y (1985) Life types of spider mites. In: Helle W, Sabelis MW (eds) Spider mites-their biology, natural enemies and control. Elsevier Science Publishing, Amsterdam, The Netherlands, World Crop Pests, vol1A, pp 253-264

Saito Y (1986) Biparental defence in a spider mite (Acari: Tetranychidae) infesting Sasa bamboo. Behav Ecol Sociobiol 18:377-386

Saito Y (1995) Sociobiological aspects of spider mite life types. J Acarol Soc Jap 4:55-67

Saito Y (1997) Sociality and kin selection in Acari. In: Choe JC, Crespi BJ (eds) The evolution of social behaviour in insects and arachnids. Cambridge University Press, Cambridge, pp 443-457 
Sato Y, Saito Y, Sakagami T (2003) Rules for nest sanitation in a social spider mite, Schizotetranychus miscanthi Saito (Acari: Tetranychidae). Ethology 109:713-724

Schaller F (1971) Indirect sperm transfer by soil arthropods. Annu Rev Entomol 16:407-446

Schliesske J (1977) Dispersal and food-plant range of Aculus fockeui Nal. \& Trt. (Acari: Eriophyoidae) and of the species associated with it. Meded Fac Landbouwwet Rijksuniv Gent 42:1343-1351

Schliesske J (1979) Vorkommen und arten der verbreitung freilebender gallmilben (Acari: Eriophyoidea) an Prunus spp. in Niedersachsen. Zool Beitr 25:1-12

Schliesske J (1990) On the gall mite fauna (Acari: Eriophyoidea) of Cocos nucifera L. in Costa Rica. Plant Res Dev 31:74-81

Shuster SM, Wade MJ (2003) Mating systems and strategies. Princeton University Press, Princeton and Oxford, p 533

Shvanderov FA (1975) Role of phoresy in the migration of Eriophyoidea. Zool Zh 54:458-461

Sih A (1987) Predators and prey lifestyles: an evolutionary and ecological overview. In: WCh Kerfoot, Sih A (eds) Predation. Direct and indirect impacts on aquatic communities. University Press of New England, Hanover and London, pp 203-224

Simmons LW (2001) Sperm competition and its evolutionary consequences in insects. Princeton University Press, Princeton, NJ, p 434

Singer MC, Thomas CD, Billinton HL, Parmesan C (1989) Variation among conspecific insect populations on the mechanistic basis of diet breadth. Anim Behav 37:751-759

Skoracka A (2008) Reproductive barriers between populations of the cereal rust mite Abacarus hystrix confirm their host specialization. Evol Ecol 22:607-616

Skoracka A, Kuczyński L (2006) Is the cereal rust mite, Abacarus hystrix really a generalist?-testing colonization performance on novel hosts. Exp Appl Acarol 38:1-13

Skoracka A, Kuczyński L, Rector BG (2007) Divergent host acceptance behaviour suggests host specialization in populations of the polyphagous mite Abacarus hystrix (Acari: Prostigmata: Eriophyoidae). Environ Entomol 36(4):899-909

Slykhuis JT (1955) Aceria tulipae Keifer (Acarina, Eriophyoidae) in relation to the spread of wheat streak mosaic. Phytopathology 45:116-128

Slykhuis JT, Andrews JE (1953) Wheat streak mosaic in Alberta and its control. Mimeographed unnumbered publications. Canadian Dept. Agric. Sci. Exper. Farms Services, Lethbridge, Alberta, August

Smith BD (1959) Effects of temperature and photoperiod on black currants and on the behaviour of the gall mite (Phytoptus ribis Nal.). A. R. Long Ashton agric, hort. Res Stat 13:7-138

Smith BD (1960) The behaviour of the black currant gall mite (Phytoptus ribis Nal.) during the free living phase of its life cycle. A. R. Long Ashton agric, hort. Res. Stat 13:130-136

Somchoudhury AK, Choudhury AK, Mukherjee AB (1985) Mite vectors and their trapping. In: Mukhopadhyay S, Ghosh MR (eds) Use of traps of pest/vector research and control. Proc. nat. seminar, Bidhan Chandra Krishi Viswavidyalaya, Mohanpur, West Bengal, Kalyani, India, March 10-11, 1984:41-50

Stam E, Isaaks A, Ernsting G (2002) Distant lovers: spermatophore deposition and destruction behaviour by male springtails. J Insect Behav 15:253-268

Staples R, Allington WB (1956) Streak mosaic of wheat in Nebraska and its control. Univ Nebr Agric Exp Stn Res Bull 178:41

Staples R, Allington WB (1959) The efficiency of sticky traps in sampling epidemic populations of the eriophyoid mite Aceria tulipae (K.), vector of wheat streak mosaic virus. Ann Entomol Soc Am 52:159-164

Sternlicht M (1969) Effect of different wave lengths of light on the behaviour of an Eriophyoid bud mite, Aceria sheldoni. Entomol Exp Appl 12:377-382

Sternlicht M, Goldenberg S (1971) Fertilisation, sex ratio and post embryonic stages of the citrus bud mite Aceria sheldoni (Ewing) (Acarina: Eriophyoidae). Bull Entomol Res 60:391-397

Sternlicht M, Griffiths DA (1974) The emission and form of spermatophores and the fine structure of adult Eriophyes sheldoni (Ewing) (Acarina: Eriophyoidae). Bull Entomol Res 63:561-565

Sternlicht M, Goldenberg S, Cohen M (1973) Development of the plum gall and trials to control its mites Acalitus phloeocoptes (Eriophyoidae, Acarina). Ann Zool Ecol Anim 5:365-377

Suhonen J, Rentala MJ, Henkavaara J (2008) Territoriality in odonates. In: Córdoba-Aguilar A (ed) Dragonflies and damselflies: model organisms for ecological and evolutionary research. Oxford University Press, Oxford, New York, pp 203-219

Sumangala K, Haq MA (2005) Diurnal periodicity and dispersal of coconut mite, Aceria guerreronis Keifer. J Entomol Res 29:303-307

Tanaka H, Shibao M (2003) A pattern of occurrence and dispersal of the tomato russet mite, Aculops lycopersici (Massee) in a tomato greenhouse. Proc Kansai Pl Prot Soc 45:23-27 
Thistlewood HMA, Clements DR, Harmsen R (1996) Stigmaeidae. In: Lindquist EE, Sabelis MW, Bruin J (eds) Eriophyoid mites-their biology, natural enemies and control. Elsevier Science Publishing, Amsterdam, The Netherlands, World Crop Pests, vol 6, pp 457-470

Thomas JA, Hein GL (2003) Influence of volunteer wheat plant condition on movement of the wheat curl mite, Aceria tosichella, in winter wheat. Exp Appl Acarol 31(3-4):253-268

Thomas RH, Zeh DW (1984) Sperm transfer and utilization strategies in arachnids: ecological and morphological constrains. In: Smith RL (ed) Sperm competition and the evolution of animal mating systems. Academic Press, Orlando, Fla. (USA), pp 179-221

Thompson JN, Pellmyr O (1991) Evolution of oviposition behaviour and host preference in Lepidoptera. Annu Rev Entomol 36:65-89

Thornhill R, Alcock J (1983) The evolution of insect mating systems. Harvard University Press, Cambridge, p 547

Van Dinther JBM (1951) [Phyllocoptes gracilis as a cause of yellow leaf spots on Raspberry] Tijdschrift over Plantenziekten 57:81-94 (In German)

Vuorisalo T, Walls M, Niemel P, Kuitinen H (1989) Factors affecting mosaic distribution of galls of an eriophyoid mite, Eriophyes laevis, in alder, Alnus glutinosa. Oikos 55:370-374

Waite GK (1999) New evidence further incriminates honey-bees as vectors of lychee erinose mite Aceria litchii (Acari: Eriophyiidae). Exp Appl Acarol 23(2):145-147

Waite GK, McAlpine JD (1992) Honey bees as carriers of lychee erinose mite Eriophyes litchi (Acari: Eriophyiidae). Exp Appl Acarol 15:299-302

Walter DA (1996) Living on leaves: mites tomentia and leaf domatia. Annu Rev Entomol 41:101-114

Walter D, Proctor H (1999) Mitesecology, evolution and behaviour. UNSW Press, CABI Publishing

Wedell N, Gage MJG, Parker GA (2002) Sperm competition, male prudence and sperm-limited females. Trends Ecol Evol 17:313-320

Westphal E, Manson DCM (1996) Feeding effects on host plants: gall formation and other distortions. In: Lindquist EE, Sabelis MW, Bruin J (eds) Eriophyoid mites-their biology, natural enemies and control. Elsevier Science Publishing, Amsterdam, The Netherlands, World Crop Pests, vol 6, pp 231-242

Wilson EO (1971) The insect societies. Belknap Press, Cambridge, p 548

Witte H (1991) Indirect sperm transfer in prostigmatic mites from phylogenetic viewpoint. In: Schuster R, Murphy PW (eds) The Acari. Chapman and Hall, London, pp 137-176

Witte H, Döring D (1999) Canalized pathway of change and constraints in evolution of reproductive modes of microarthropods. In: Bruin J, Geest LPS, Sabelis MW (eds) Ecology and evolution of the Acari. Kluwer Academic Publishers, Dordrecht, pp 15-43

Yanagida H, Saito Y, Mori K, Chittenden AR (2001) Egg-depositing behaviour as a predator avoidance tactic of Yezonychus sapporensis Ehara (Acari, Tetranychidae). J Ethol 19:63-66

Zhao S, Amrine JW Jr (1997a) A new method for studying aerial dispersal behaviour of eriophyoid mites (Acari: Eriophyoidea). Syst Appl Acarol 2:107-110

Zhao S, Amrine JW Jr (1997b) Investigation of snowborne mites (Acari) and relevance to dispersal. Int J Acarol 23:209-213 